\title{
توظيف الإدراك البصري والتقنيات الجرافيكية في تصميم الصورة التعليمية
}

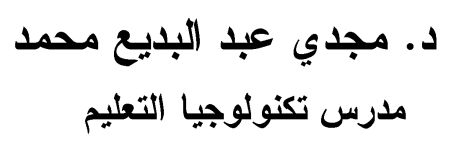

كلية التربية النوعية - جامعة طنطا

\author{
د. كمال أحمد شريف \\ رئيس قسم التصوير الفوتوغرافي لفئ \\ و والسينما والتلفزيون سابقا \\ كلية الفنون التطبيقية - جامعة حلوان
}

مجلة|لاراسات التربوية والاسائية ـ كلية التربية ـ جامعة دمنهور

المجلد الخامس العد (1) لسنة 2013 
توظيف الإدر الك البصري والتقتيات الجر افيكية في تصميم الصورة التعليمية

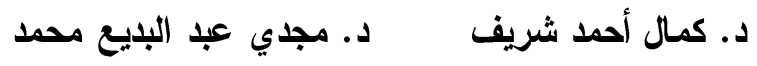

مقدمة

يتسم عصرنا الحالي بالتقام العلمي و التقني الهائل و الذي ساهم في إحــداث

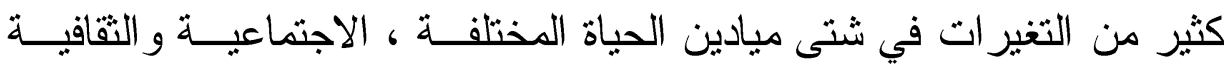

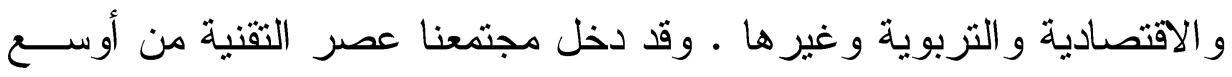

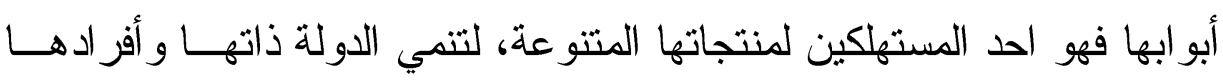

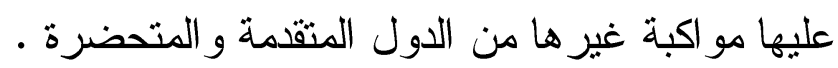

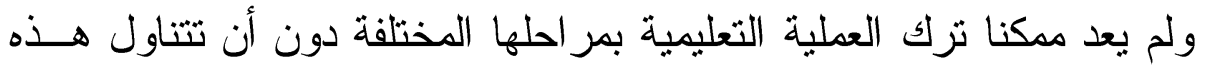

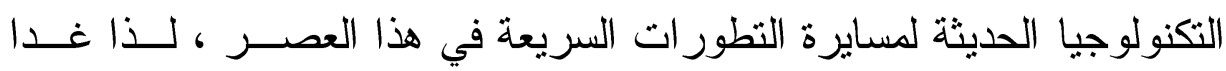

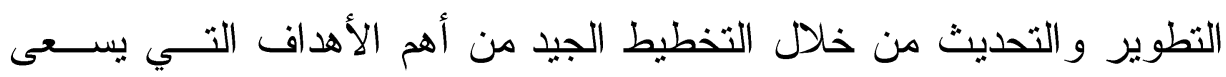
التزبويون لتحقيقها لتلبية احتياجات المجتمع ومطالب نمو المتعلمين لقد أدركت أمم كثيرة أهمية التخطيط لبناء مجتمع متقدم يكون أساسه العلم و المعرفة .

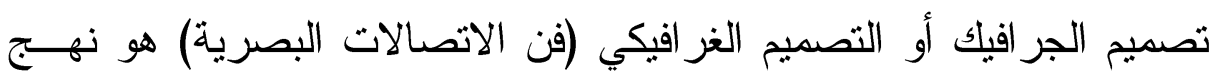
إبداعي يقوم به مصمم أو مجمو عة من المصممين ويتعاون على تتفيذ معطياته

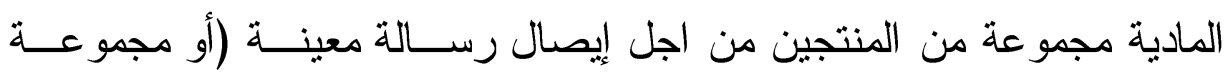

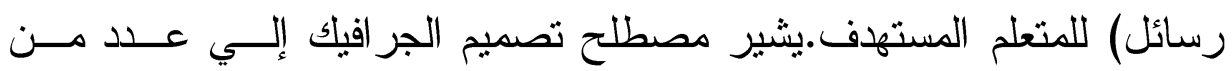

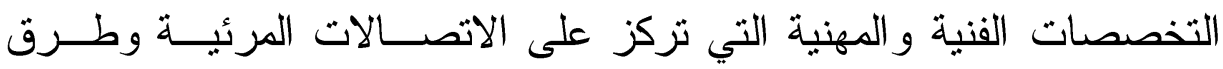

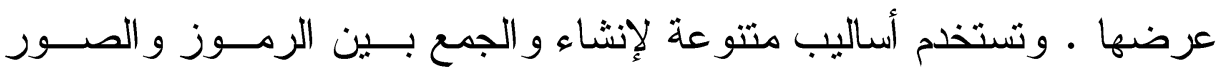

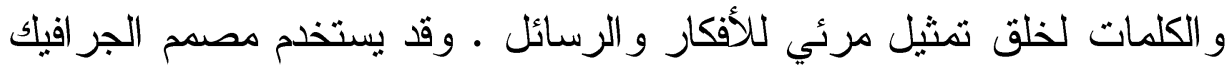

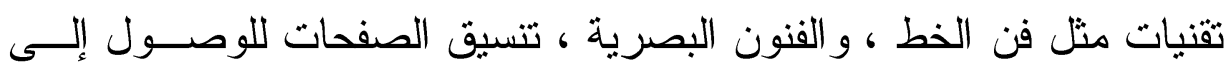

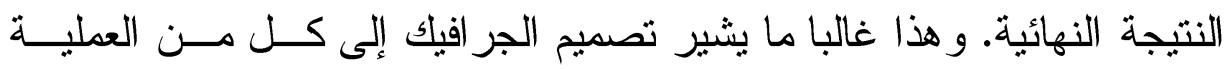
(التصمي) التي من خلالها يتم إنشاء التو اصل وكذلك المنتجات (التصاميم) . 
التعلم بالاستبصار يحدث بصورة مفاجئة : أب أن التوصل للحل يتم بصــورة

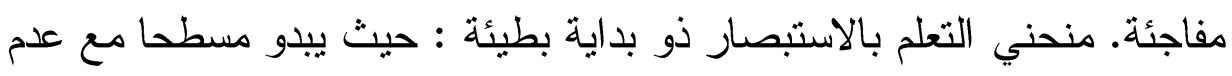

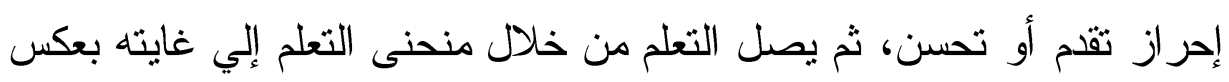
منحنى التعلم بالمحاولة و الخطأ الذي يحدث التحسن فيه بصورة لدمن تدريجية .

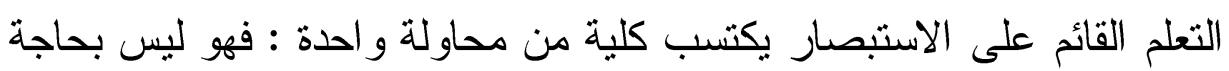

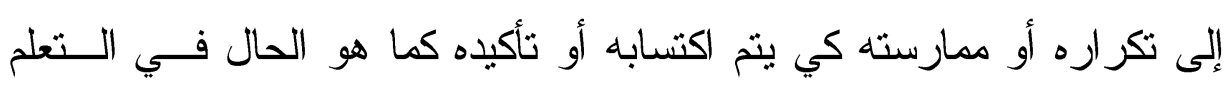

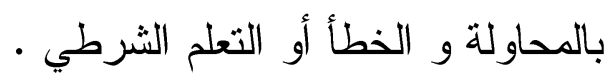
التعلم بالاستبصار تعلم قائم على الفهم: فهو تعلم قائم على الفهم يمكن تعميمه

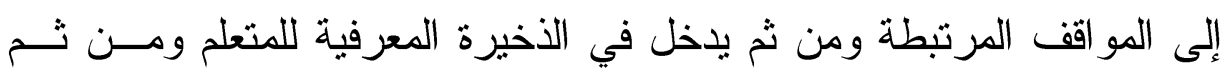

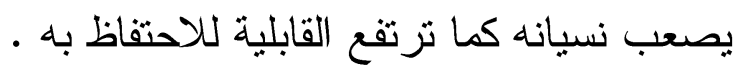

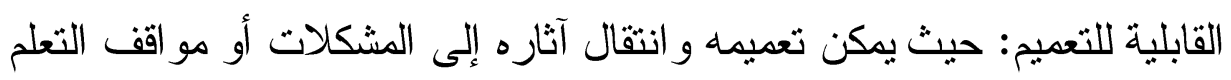

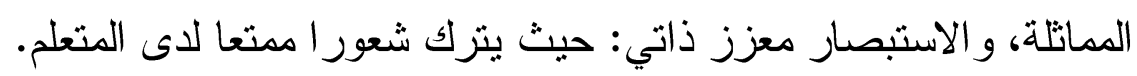

\section{مشكلة (لبحث}

تعتمد عملية تصميم الرسوم التعليمية و إنتاجها على قدرة المصمم الإبتكارية في التخطيط الكامل لشكل شئ ما، و إنشائه بطريقة ليست مرضية من الناحية

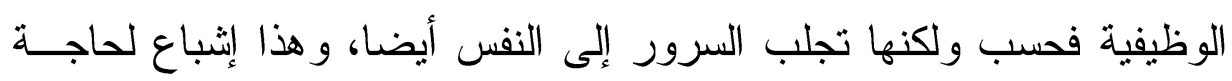
المتعلم نفعيا و علميا وجماليا في وقت و واحد . ن.

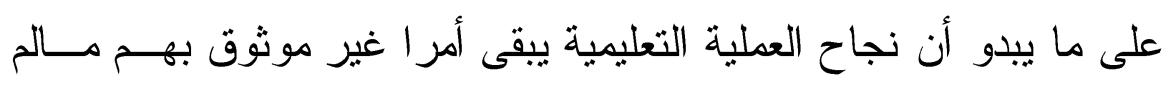

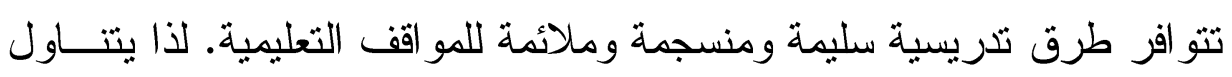

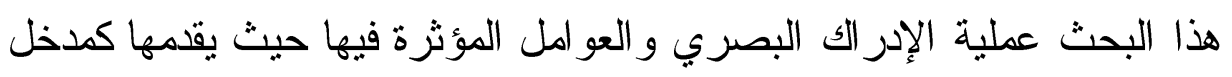

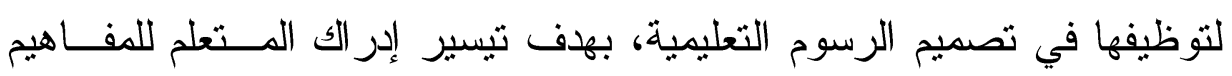

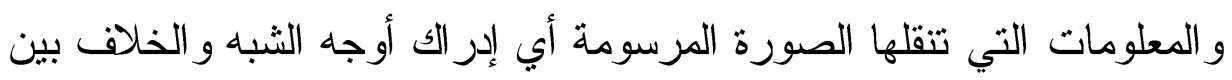
الأشياء و الرموز بسرعة ودقة ويتوقف نوع الاستجابة على مو اصفات الصورة 
المرسومة وعلى الخصائص النفسية و العقلية التي يتسم بها المتعلم وخبراتــه السابقة، ومن ثم فإن اعتبارين أساسين .

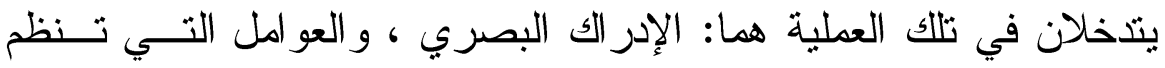

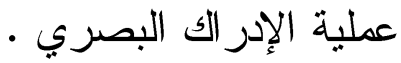
إن استخدام الأساليب التقليدية في التذريس وقلة متابعة المعلمين لما يستجد في

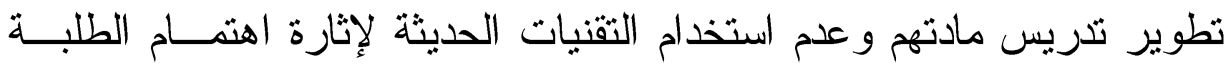

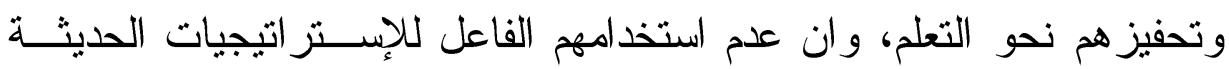
إنعكس سلبا على مستوى التحصيل الار اسي للمتعلمين ومن هنا تجلت مشكلة البحث في الاسئلة التالية :

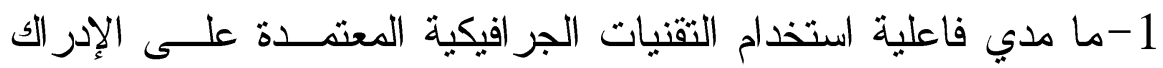
البصري في تصميم الصورة التعليمية. 2- هل يساهم استخدام التقنيات الجر افيكية المعتمدة على الإدر الك البصري بشكل جيد في إنجاح العملية التعليمية.

أهدف (لإث :

إن تحقيق الأهداف التعليمية تحتاج إلي طرق وأساليب حديثة تدور حــول المتعلمين وتجعلهم محور النشاط و العمل كي تساعدهم على فهم المادة التعليمية و إدر الك معانيها مع شئ من التوجيه و الإرشاد منى قبل المعلم في تتمية مختلف

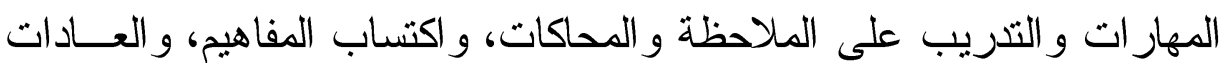
و الاتجاهات، و أساليب التفكير . يهذف البحث إلى :

إلقاء الضوء على أهم التحديات التي نو اجه تصميم الصورة الجر افيكية

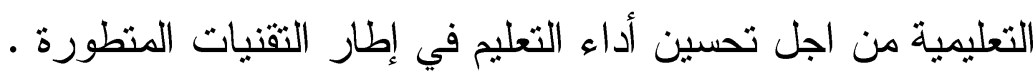

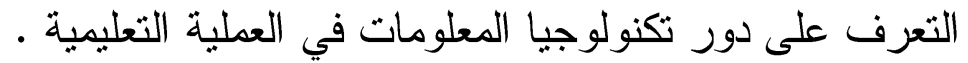

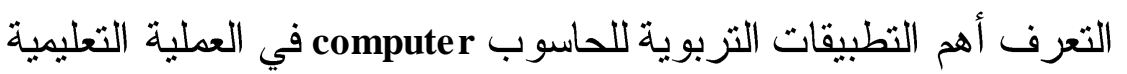




\section{• مصطات الإر اسةة :}

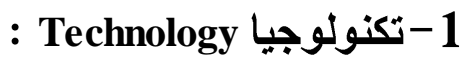

تعني الاستخدام الأمثل للمعرفة العلمية وتطبيقها وتطويعها لخدمة الإنسان

ورفاهيته. (Read Bain,1973)

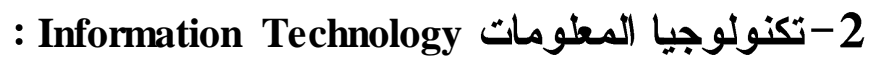

و هي موارد المعلومات في المؤسسات المختلفة، ومستخدميها و الإدارة التي تشرف عليه، بما في ذلك البنية التحنية، وكل نظم المعلومات الأخري في هذه الهي المؤسسات.

و هي نظم معلومات معتمدة عل الحاسوب في جمع ومعالجة وتخزين وتحليل

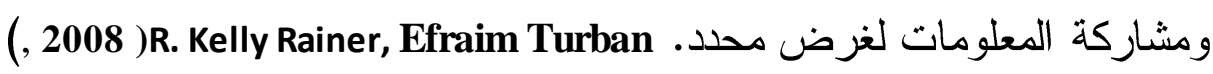

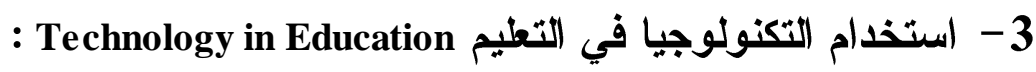

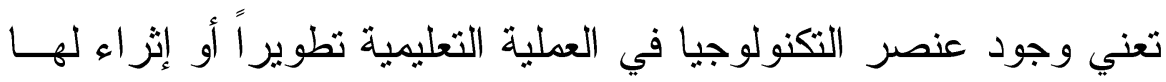
وتيسير العمليتي التعليم و التعلم ، ويقصد بذلك استخدام الوسائل التكنولوجية في

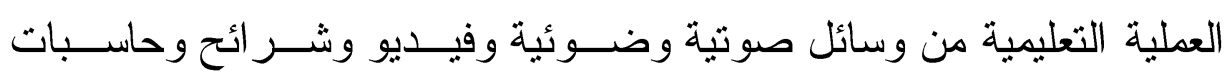

$$
\text { مفهوم الصورة الأهنية : ماحد اللقاني، 2003) }
$$

تتعدد التعريفات و الدراسات الخاصة بتعريف الصورة الذهنية ولكننا ســوف

نشير إلي بعض المفاهيم ذات الصلة بموضوع البحث .

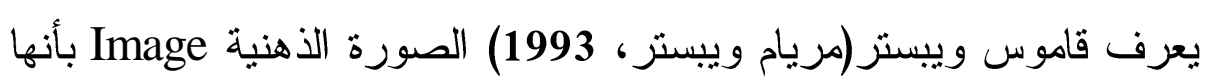

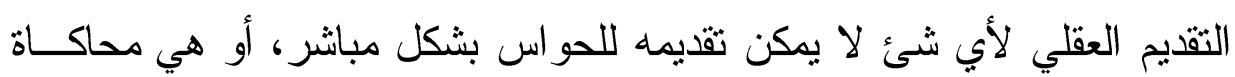

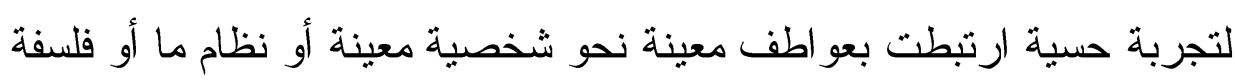

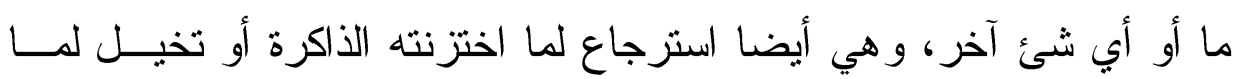
أدركته حواس الرؤية أو الثم أو السمع أو اللمس أو التذوق . 
إن مفهوم الصورة الذهنية ظهر كمصطلح متعارف عليه في أوائـلـل القــرن

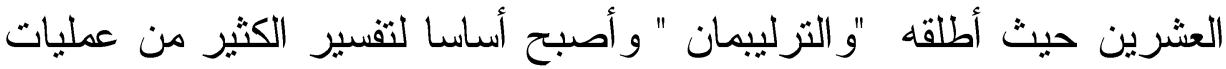
التأثير التي بها وسائل الإعلام وتستهدف بشكل رئيسي ذهن الإنسان . لعل هذا المفهوم سينمو ويتطور ويصبح شائعا في لغة الاتصال فإذا كانــــ الكلمة بصفة عامة وسيلة لنقل المعنى أو التعبير عن العو اطف، و إذا كان هــــا

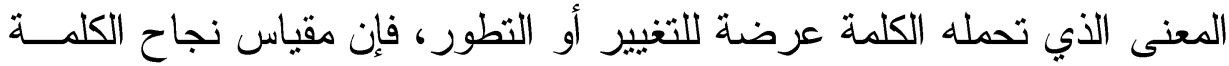
في نقل المعنى يتمثل في مدى قدرتها على تصوير ما تشير إليه من هذا العالم في داخل العقل البشري . وبمعنى مختصر فإن نجاح الكلمة يتوقف على قدرتها على تصوير العـالم

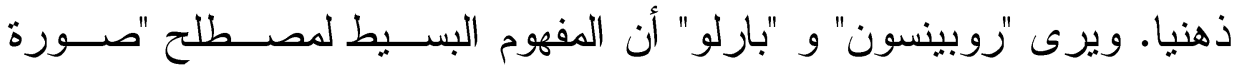
المنظمة" يعني ببساطة الصورة العقلية التي تتكون في أذهان الناس عن المنظمة بلنة

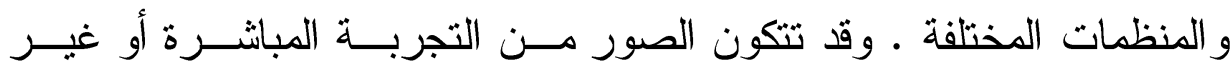
المباشرة.

ويقول (علي عجوة، 2003) في تعريفه للصورة الذهنية في كتابه "العلاقات العامة و الصورة الذهنية" :إذا كان مصطلح الصورة الذهنية لا يعني بالنســبة لهن

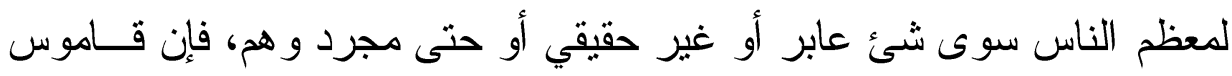
ويستز في طبعته الثانية قد عرض تعريفا لكلمة Image بأنها تثير إلى التقديم فئري العقلي لأي شئ لا يمكن تقديمه للحو اس بشكل مباشر ، أو هي هي إحياء أو محاكاة

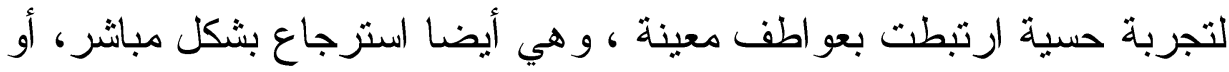

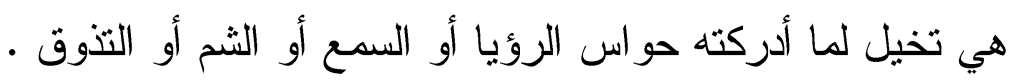
الصورة الذهنية هي الناتج النهائي للانطباعات الذاتية التي تنكون في أذهي أذهـان

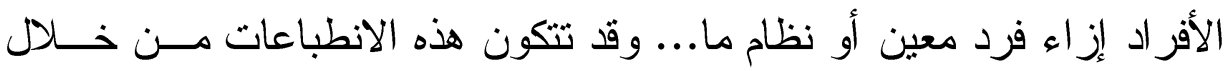

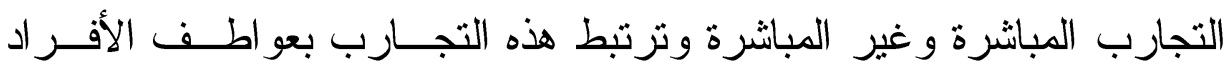
و اتجاهاتهم و عقائدهم بغض النظرعن صحة المعلومات التي تتضمنها خلاصة 
هذه التجارب فهي في النهاية تمثل دافعا صادقا بالنسبة لأصحابها ينظرون من

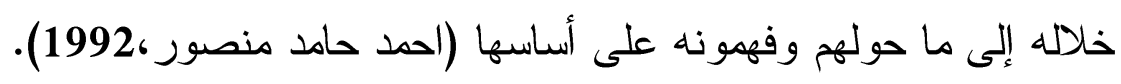

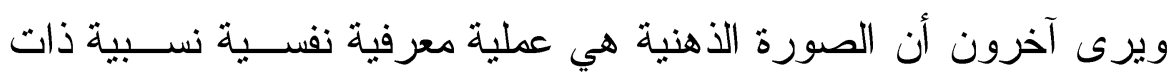

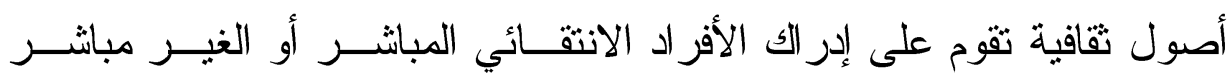

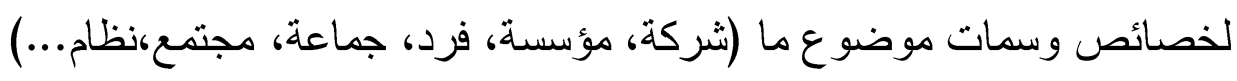

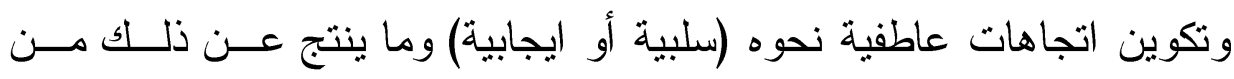

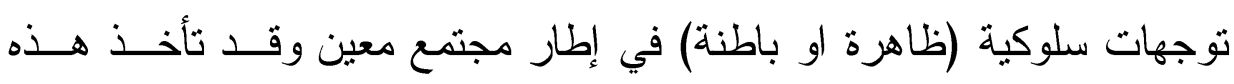

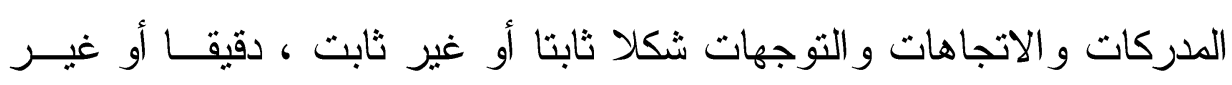
دقيق. • أن الصورة عملية : ديناميكية متفاعلة تمر بمر احل متعددة تتأثر كل مرحلة

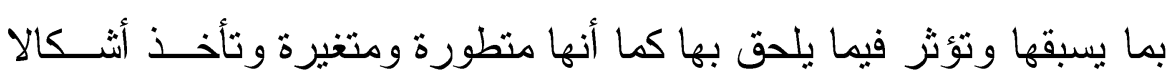

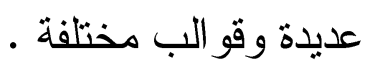

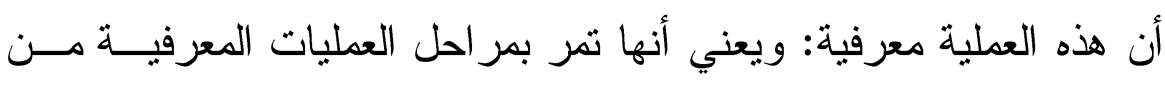
إدر الك وفهم و تنكر • وتخضع للمتغير ات و العو امل التي تخضع لها لها العمليات المعرفية أو تتأثز بها.

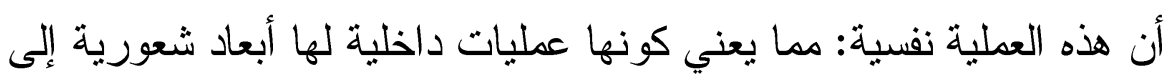

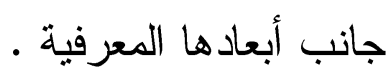

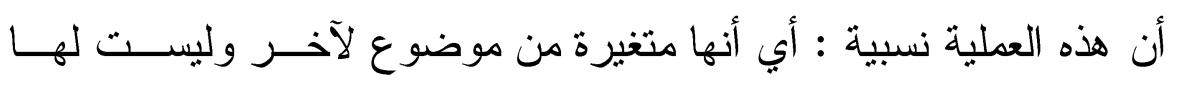

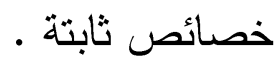
أن هذه العملية تتكون وتتطور في إطار ثقــافي معـين: أي أن الصــورة

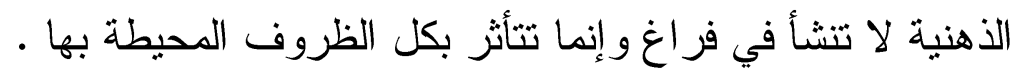
أن هذه العملية لها ثلاث مكونات : مكون إدر اكي ويعني الجانب المعلوماتي للصورة، ومكون عاطفي ويتضمن الاتجاهات العاطفية (سلبية أو ايجابية) 
نحو الظاهرة موضوع الصورة، ومكون ســلوكي ويتضـــن الســلوكيات

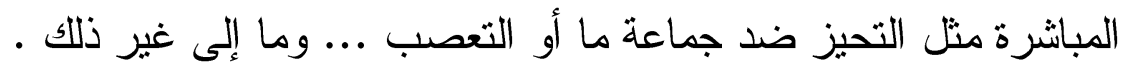

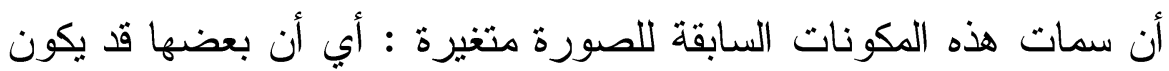
ثابتا و البعض غير ثابت، كما أن هذه الدركات و الاتجاهات و الســلوكيات

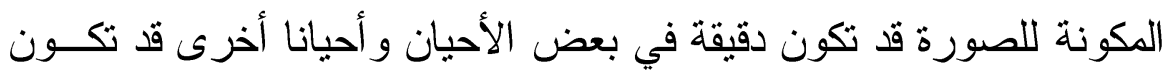

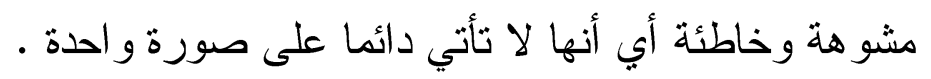

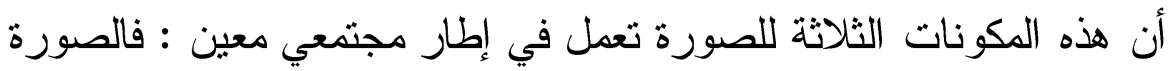
تتبع من المجتمع وتوجد فيه وتختلف تبع لخصائص وسمات كل مجتمع . تعريف التصميم

التصميم هو التخطيط الذي يرسي الأساس لصنع كائن أو نظام ، يمكن أن

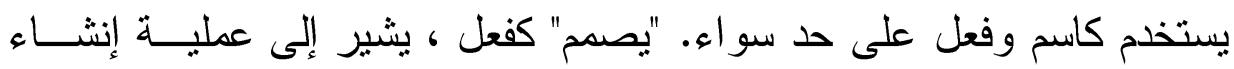

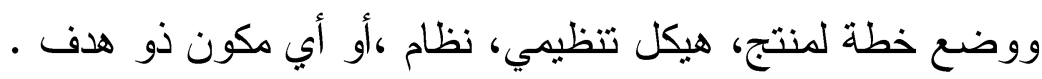

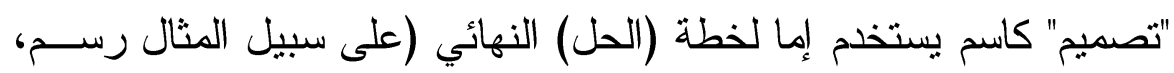
نموذج، وصف) أو نتيجة تنفيذ تلك الخطة في شكل المنتج النهائي من عمليــة • التصميم وبعيدا عن التصنيف، بأوسع معانيه لا وجود لأية قيود أخــرى، فــالمنتج

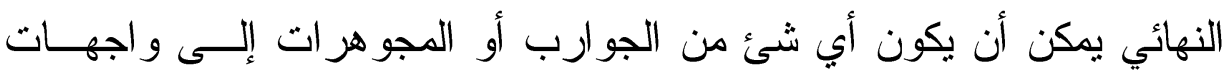

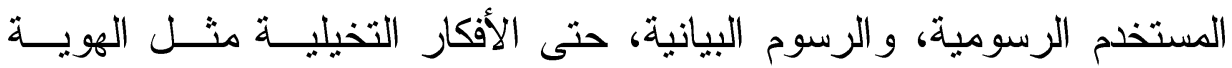

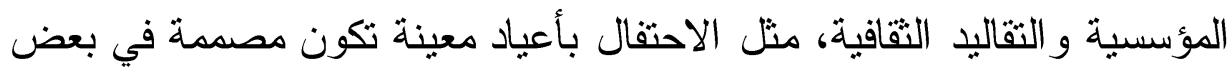
الأحيان المؤسنيان وفي الآونة الأخيرة، العمليات (بشكل عام) كانت أيضا تعامل على أنها من منتجات التصميم، مما أعطى معنى جديدا للمصطلح تصميم العمليات .

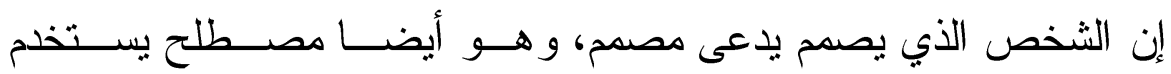
للأشخاص الذين يعملون مهنيا في احد مجالات التصميم المختلفة ، ويحدد عادة لون 
مجال التخصص إلي يتعامل معه (مثل مصمم أزياء، مصمم أفكار ، أو مصسمم على شبكة الانترنت) .

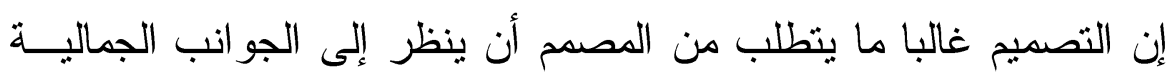

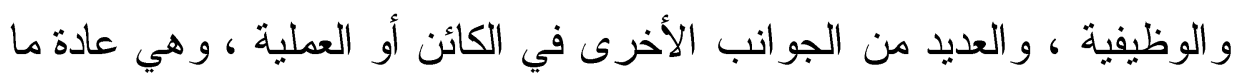

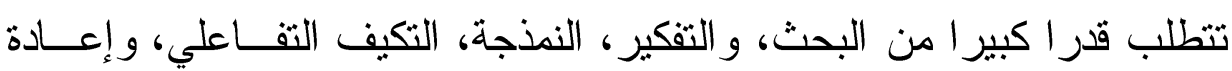

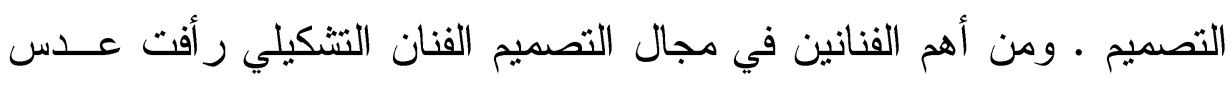

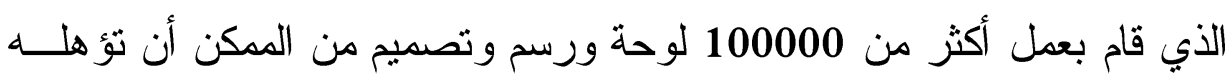
لاخول موسو عة جينز للأرقام القياسية العالمية .

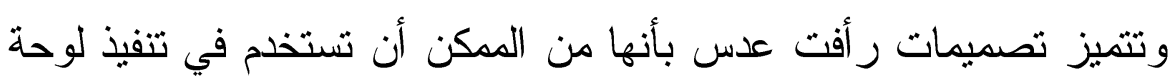

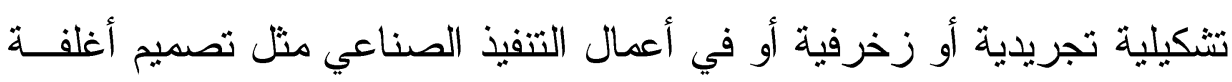

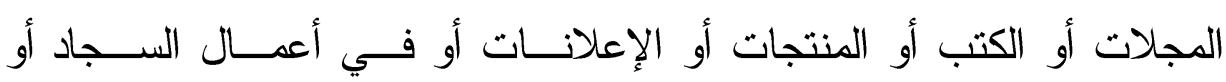

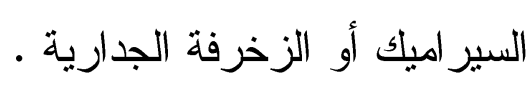

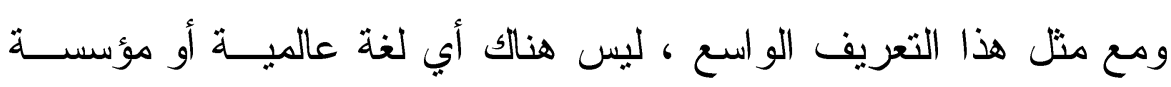

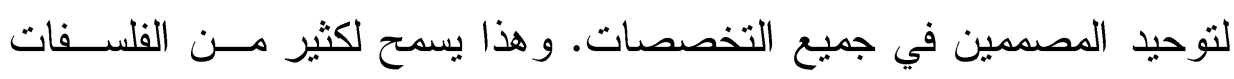

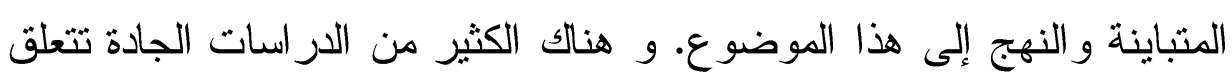

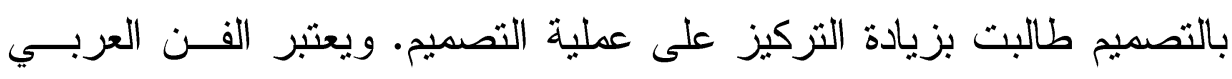

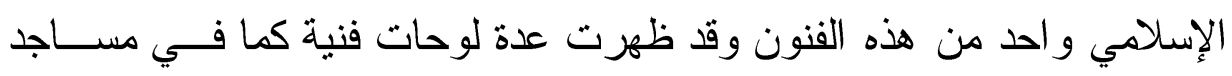

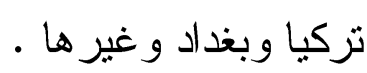
تعريف تصميم الجرافيك

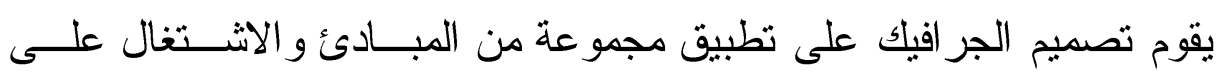

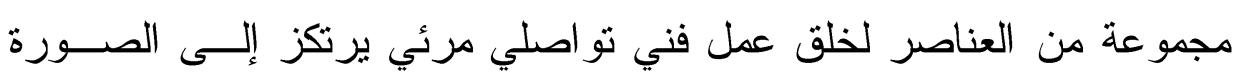

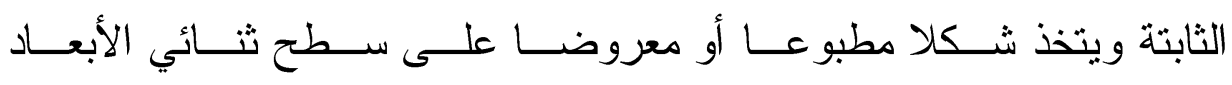
(موسي،2011). 
كان أول من أطلق تسمية (Graphic Designer) هو المصمم وليام أديسون

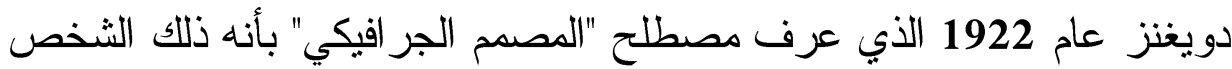

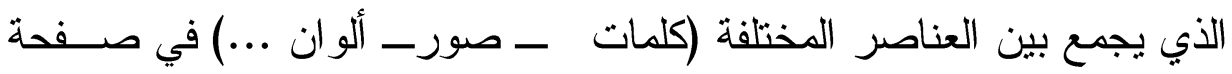

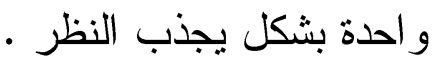

التصميم الجر افيكي مشتق من كلمة (جر اف ) ، و هي تعني (رسم بياني)،أما

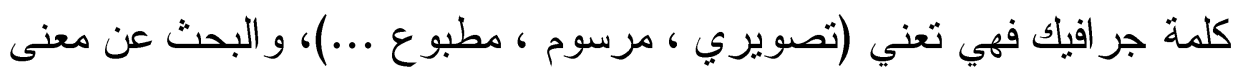

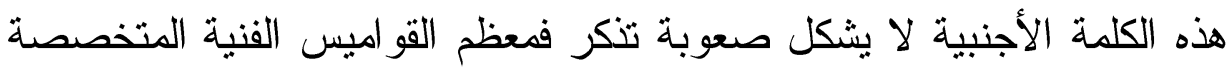

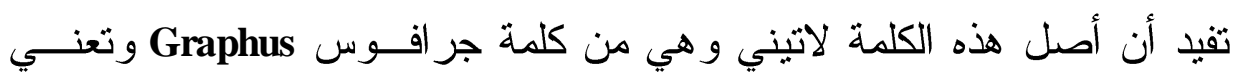
ضمن ما تعني : خط مكتوب أو مرسوم أو منسوخ، فأستعير اللفظ في اللغــات الأوروبية لكي يطلق على كل رسم بخط منسوخ ثم أصبح اسما عالميا لهذا الفن وجاء في اللغة الفرنسية هكذا (Gravure) (رمزي العربي،2009).

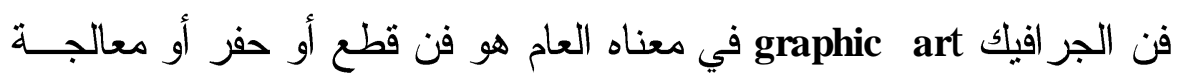

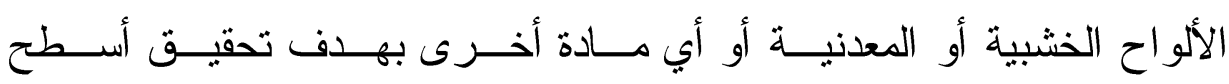
طباعية،و الحصول على تأثير ات فنية تشكيلية مختلفة عن طريق طباعتها .

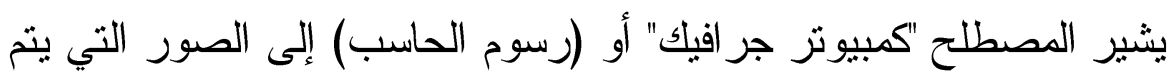
إنتاجها باستخدام الحاسب ، و التي تشمل الرسومات التوضيحية (Illustrations)

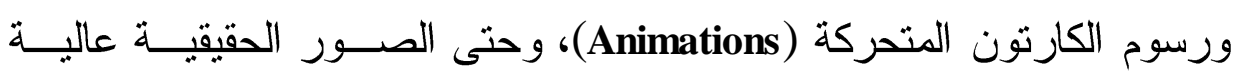
الجودة (High Resolutions Photos)، كما يستخلم نفس التعبير للإثشارة إلـى عملية سحب الصور وتلوينها وتظليلها ومعالجتها من خلال الحاسب ، وتساعدنا

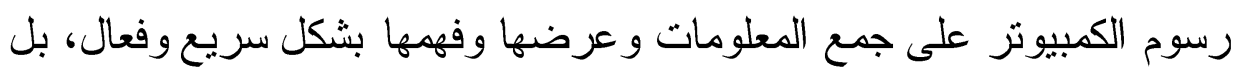

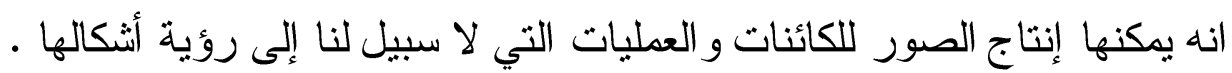

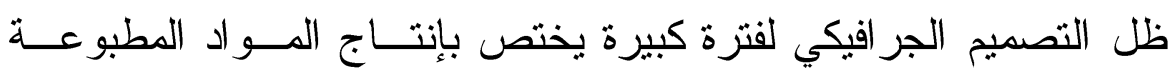

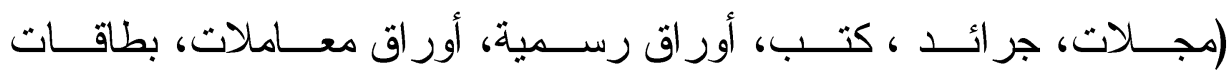

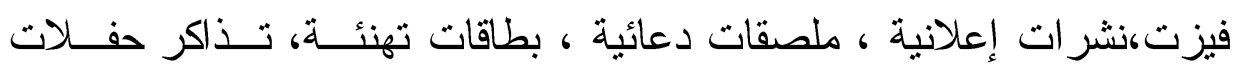


ومباريات، أختام، شعار ات، مغلفات رسائل، مغلفــات المنتجــات، صــناديق

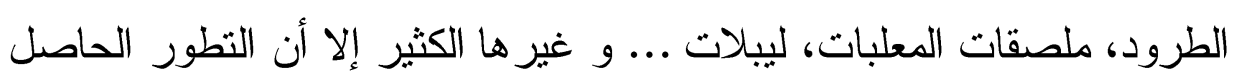
في مجال تكنولوجيا المعلومات (Information Technology) أضــاف الكثيــر للتصميم الجر افيكي فأضحى هناك فرع قائم بحد ذاته أطلات عليه اسم "الوسائل

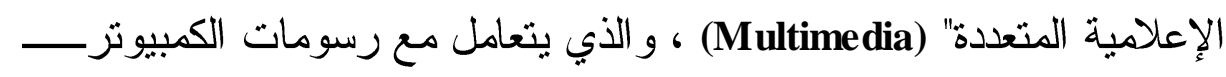

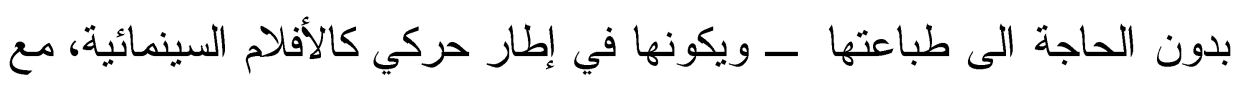

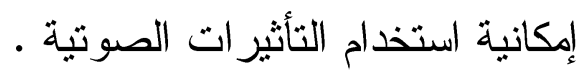
الإبداع بطريق الحاسب الآلي

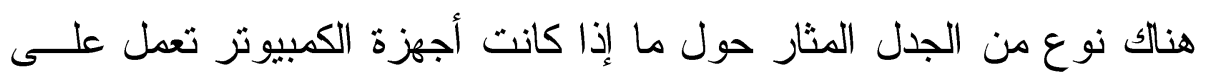

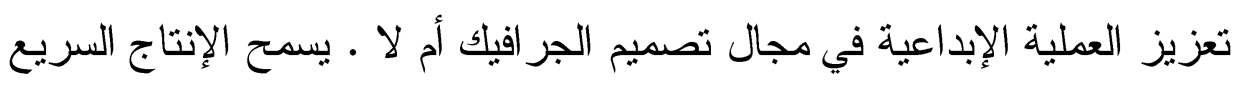

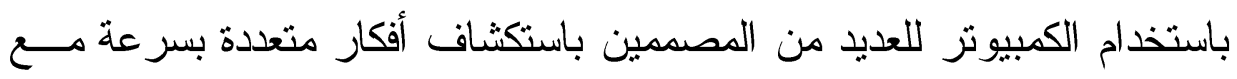

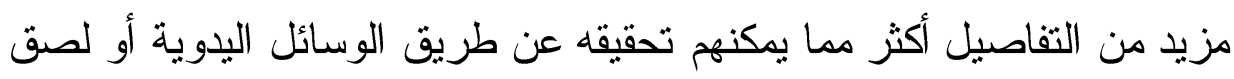

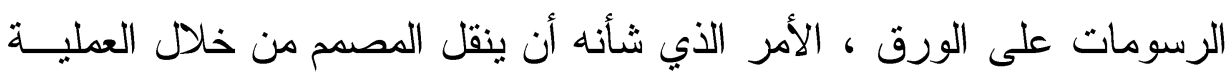

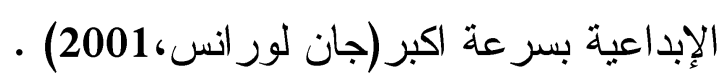

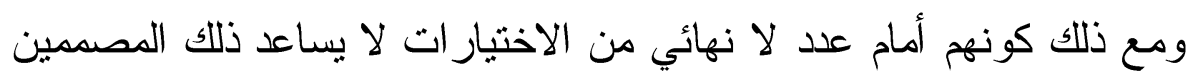

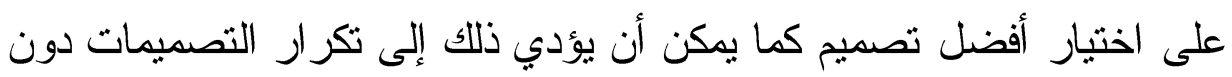
التوصل إلى نتائج و اضحة . قد يستخدم مصمم الجر افيك الاسكتشات لاستكثاف أفكار متعددة أو معقــدة

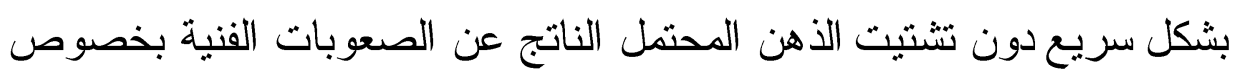

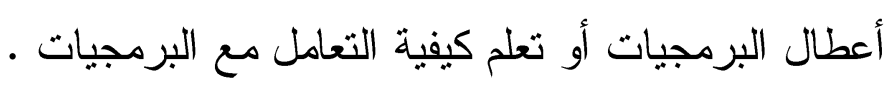

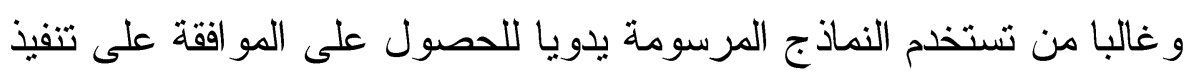
الفكرة قبل أن يقوم المصمم باستثمار الوقت لإنتاج التصاميم النهائية على جهاز

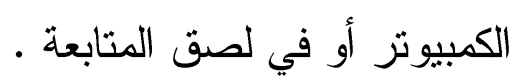


هذا وقد تستخدم نفس الصور المصغرة أو المسودات على الورق من اجــل

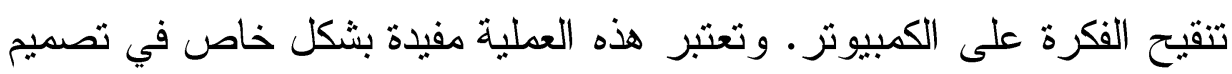

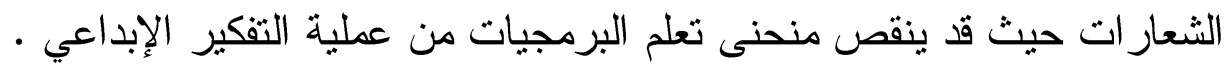

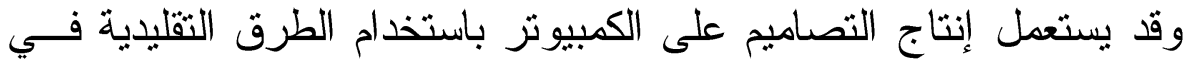

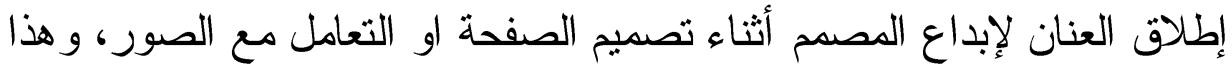
ويعمل مصمموا الجر افيك التقليديين على الاستعانة بفنانين مختصين في الإنتاج

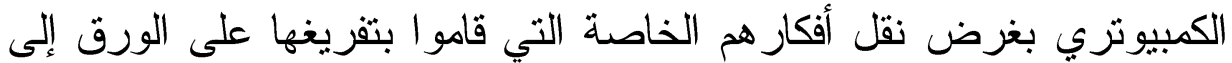

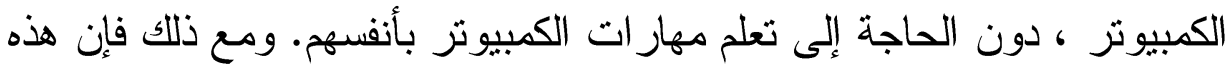

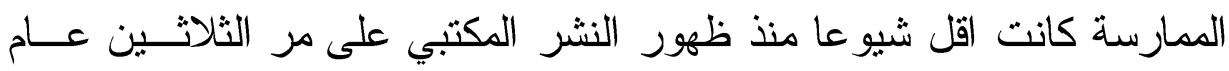
و تكامله مع دور ات التصميم الجرافيك.

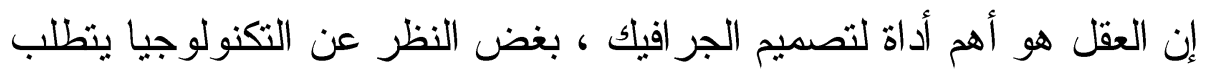
تصميم الجر افيك الحكم و الإبداع حيث لابد من وجود التفكير النقبي ، و الملاحظ

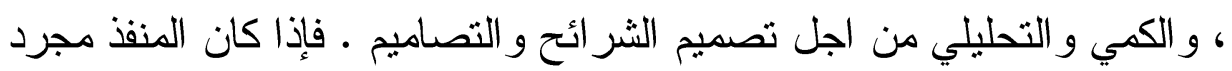

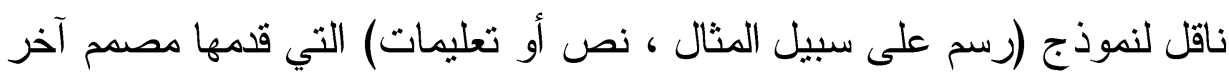

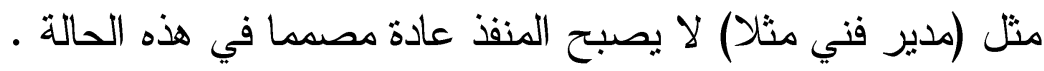
بالإضافة إلى اتخاذ قرار ات المحتوى الرئيسية ، قد تكون طريقة العـرض لهره

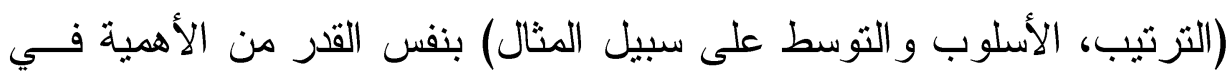

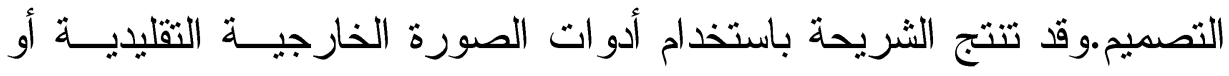

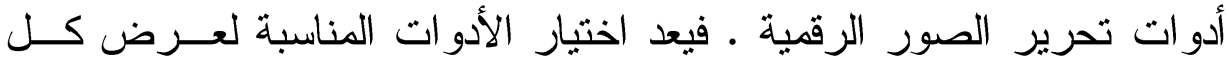

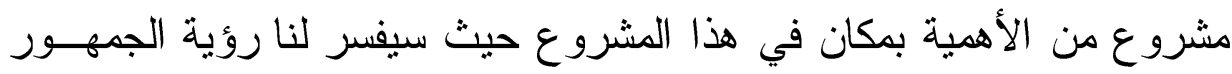

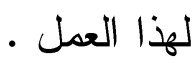

وفي منتصف ثمانينيات القرن الماضي،عمل وصول النشر المكتبي وبرمجيات فن الجر افيك على تقديم جيل من المصدمين للتعامل مع وخلق صورة الكمبيونز التي سبق تتفيذها يدويا.كما مكن تصميم الجر افيك على الكمبيوتر المصممين من من وندين 
معرفة آثار التخطيط أو الطبع على الفور، ومحاكاة تأثيرات وســائل الإعــلام

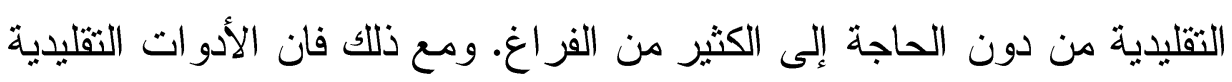

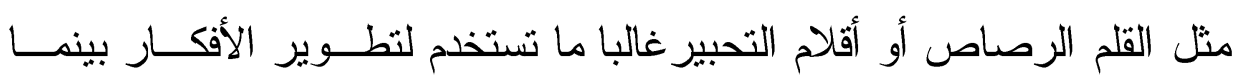

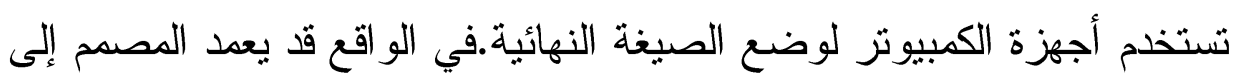

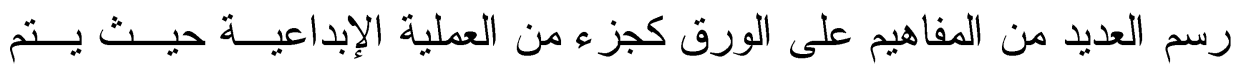

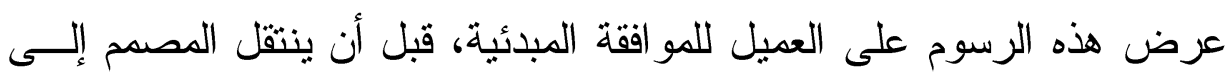

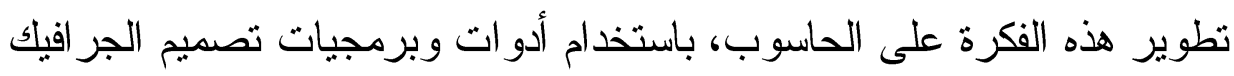

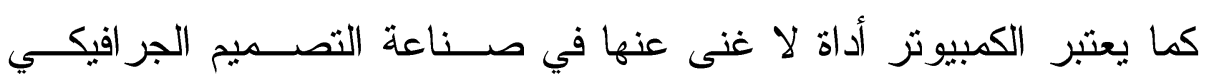

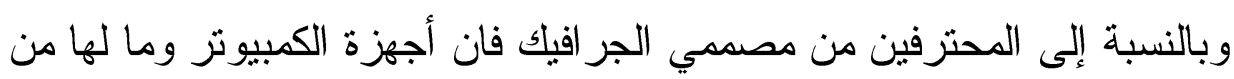
تطبيقات البرمجيات تعتبر بصورة عامة من الأدوات الأكثر فعالية في مجـــال

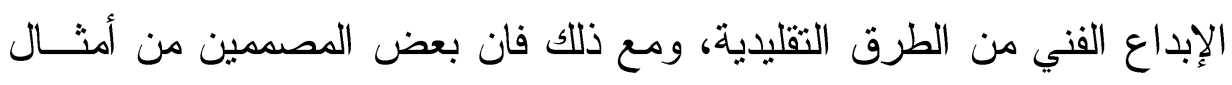

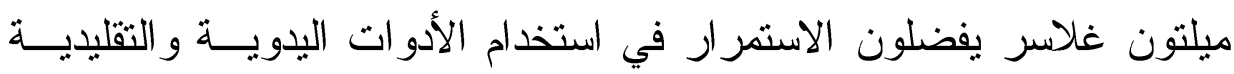

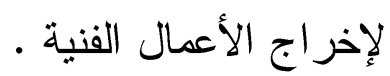
لا تأتي الأفكار الجديدة إلا من خلال تجريب الألأدو ات الأ والأســاليب ويقـوم بعض المصممين باستكثاف الأفكار باستخدام القلم و الورقة لتفادي التكوينـات التهات الحادة في كل من خطوط الكمبيوتز و الرسوم الجاهزة، أو الفلاتر مثل (أدوات

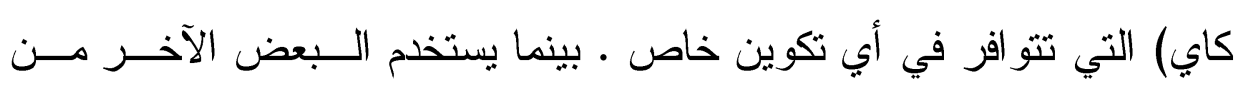

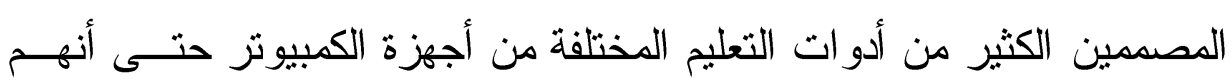
يستخدمن العصى و الطين كوسيلة من وسائل الإبداع •

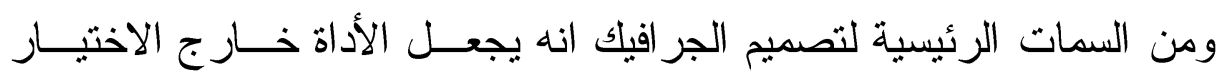

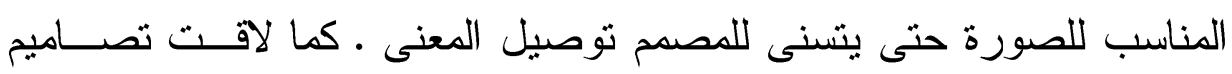

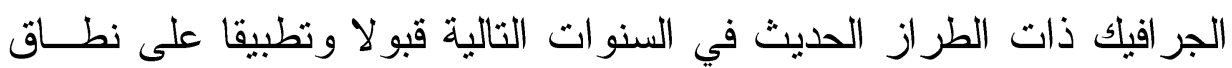
و اسع ·(كر اونش، 2000) 
تعريف الإدر الك البصري

الإدر الك البصري يمكن تعريفه بان الوسيلة التي يتصل بها الإنسان بالمؤثرات

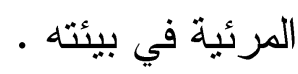
وعملية الإدر الك البصري منلها كمثل عمليات الإدر الك الأخرى لا تتم إلا بوجود العو امل الآتية : 1 - عو امل مرتبطة بالمتلقي

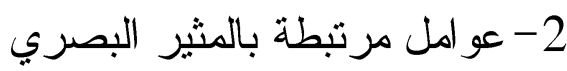

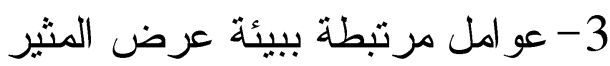

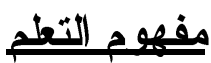

مفهوم التعلم يتصل بعمليات اكتساب السلوك و الخبرات و التغير ات التي تطر أ

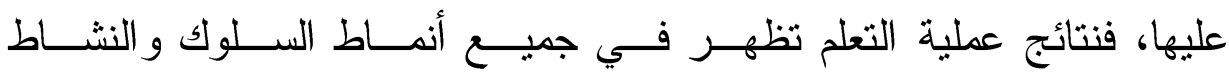

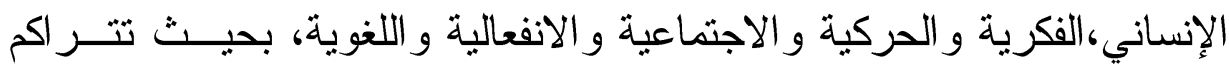

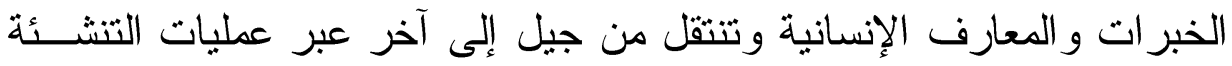
الاجتماعية و التفاعل مع العالم المادي. يشتمل التعلم الإنساني على الأنماط السلوكية البسيطة و المعقدة منها، ويتجلى

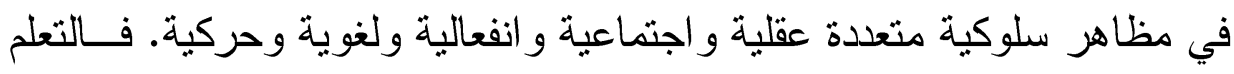

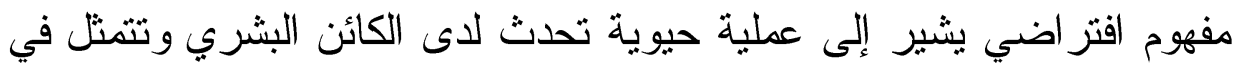
التغير في الأنماط السلوكية وفي الخبر ات، إذ من خلالها بسنطيع الفرد السيطرة

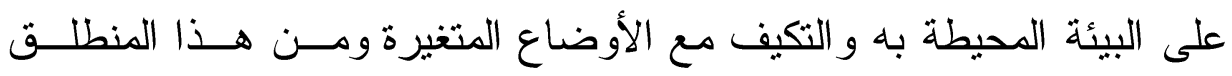

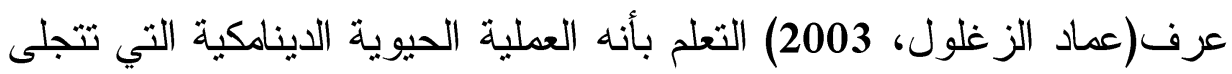

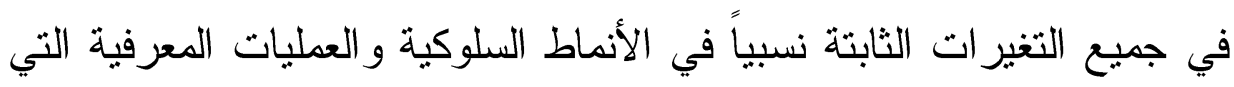

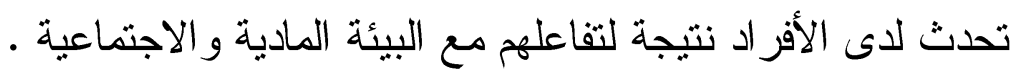

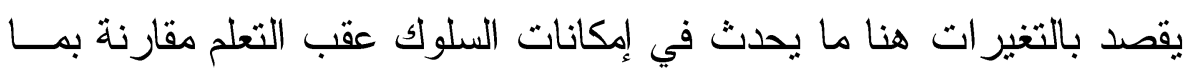
قبل التعلم، والتغير الحادث هنا يستبعد كافة صور التغير الأخرى التي لا تقوم 
على الممارسة أو الخبرة أو الاكتساب أو التذريب مثل: تو ابع النضج الفطرية كالمشي و المضغ ونحوه، وكذلك تو ابع التعب مثل رجوع الفرد من عمله وهو

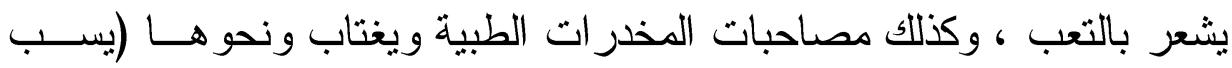

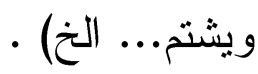

توظيف عناصر التصميم في إعداد الرسوم التعليمية :

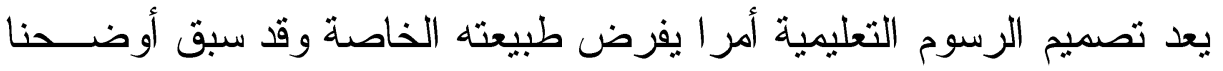

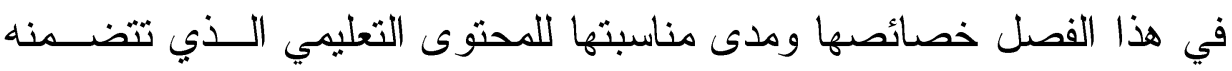

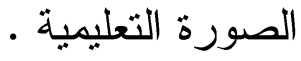

ويعتمد تصميم الصور التعليمية في مجال هذا الكتاب علـــ ثلالـــة عناصــر

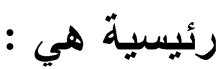
1- الخط 2- 2 الثكل 3- اللون

وسوف نتناول كلا من العناصر السابقة في مجال إعداد الرسوم التعليمية بشئ من الإيضاح

\section{توظيف الخط في الرسوم التعليمية :}

للخطوط عدة أشكال في تصميم الصور التطليمية منها :

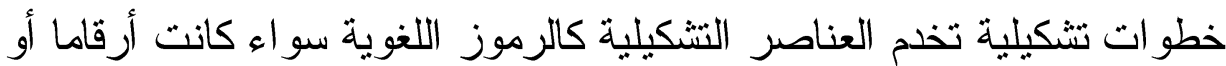
كلمات أو عناصر أخرى كالرسوم ، حيث تحيط هذه الخطوط بالعناصر السابقة وتحدد هيئتها.

و هناك خطوط أخرى وظليفتها الوصل بين عناصر تصميم الصورة التعليميــة السابق الإثارة لها ـ لهن

ويتوقف التعبير الفني على عوامل متعددة ترتبط بخصائص الخطــوط تعنــي

بذلك الاعتبارات التالية : 


$$
\text { 1- اتجاه الخط (رأسي - أفقي - مائل). }
$$

2- مدى استقامة الخط أو تعرجه أو انحنائه .

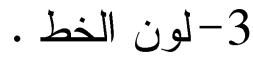

4-سمك الخط وطوله أو قصره . 5- العلاقات بين الخطوط المتجاورة .

6- الوسيلة التي استخدت في أداء الخط ( فرشاة - قلم ريشة ).

ويشمل توظيف عنصر الخط في إعداد الرسوم التعليمية ما يلي :

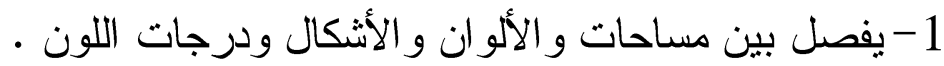

2-يمثل الدليل الذي يقوده العين إلى مركز الانتباه في الصورة.

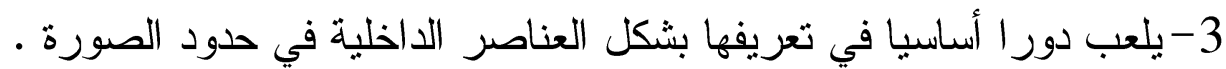
4- يحمل رسالة أو فكرة يرغب المرسل في نقلها للمتعلم وتكون محملة بمعاني أو إحساسا خاصا .

ويتبين من ذلك أن الخط إذا استخدم نظر اللاعتبار ات السابقة ســوف يكــون

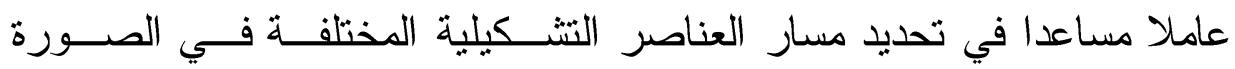
التعليمية.

\section{توظيف عنصر الشكل في تصميم الرسوم التعليمية :}

يعتبر اختيار الثكل عنصر ا أساسيا في تصميم الرسوم وذلك من حيث فيث نو عيته

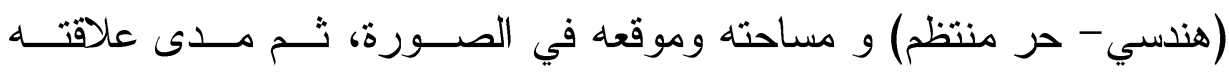

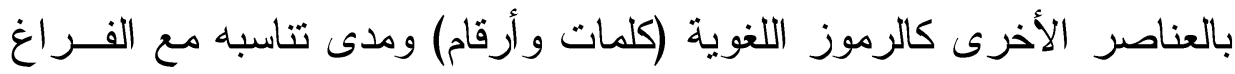
المتروك لر احة العين . والأشكال التي تتضمنها الرسوم التطيمية هي :

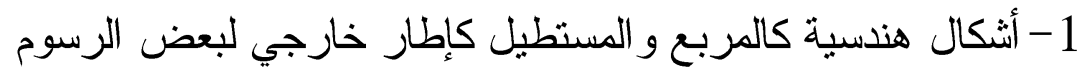
2- أثكال حرة منتظمة كالإنسان وبعض الطيور و الحيو انات و النباتات

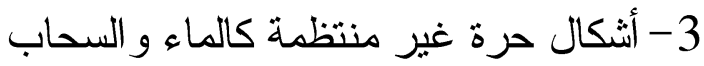


4- عناصر تشكيلية أخرى كالرموز اللغوية (كلمات و أرقام) توظيف عنصر اللون في تصميم الرسوم التطليمية :

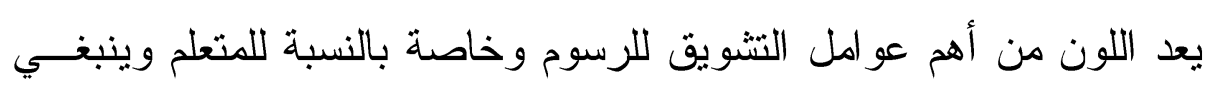

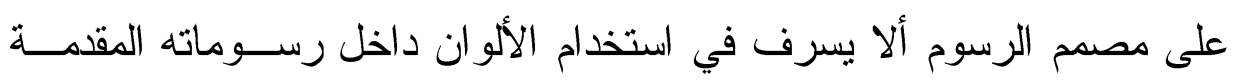

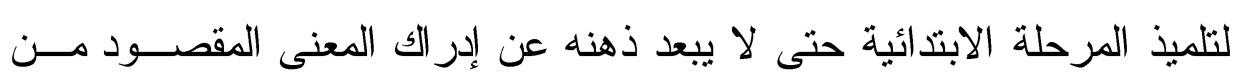

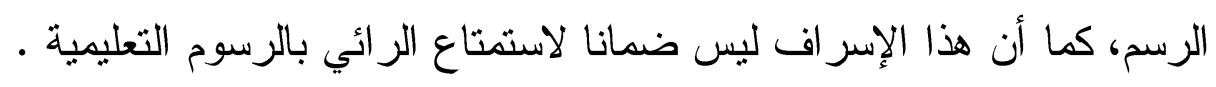

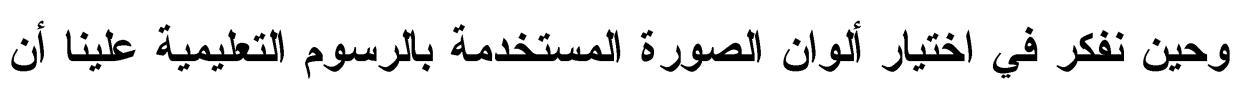

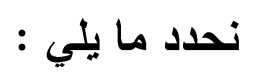
1. الطابع الذي نرغب أن يسود ألوان الصورة من حيث البرودة (ألو ان مناسبة

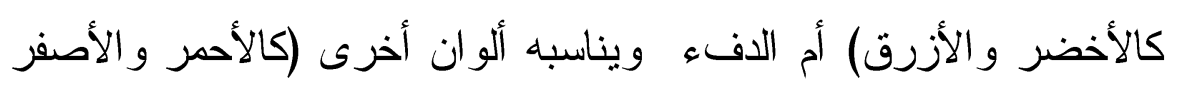
مثلا).

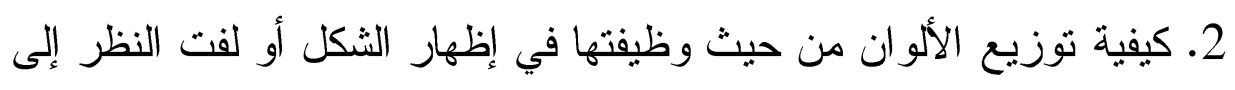

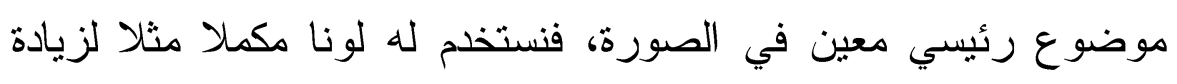
تباينه عما حوله .

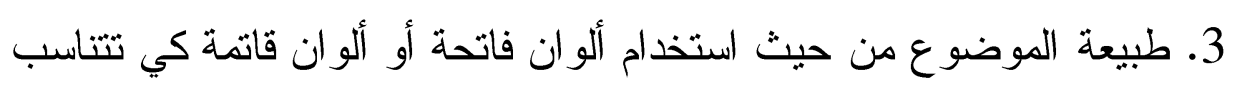

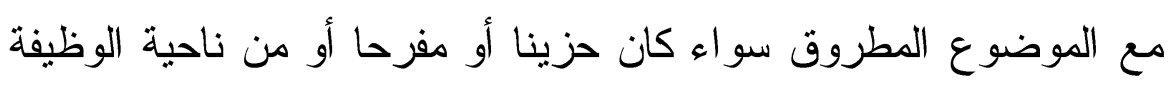

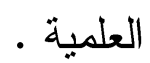

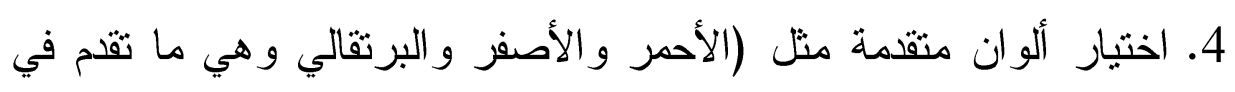

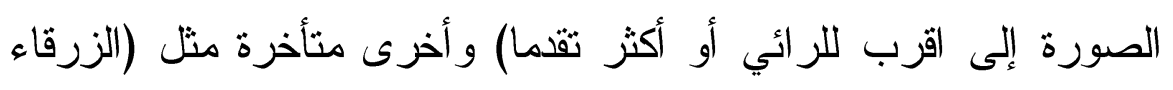

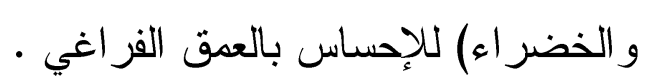

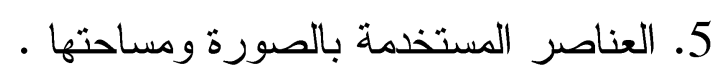

6. نو عية الجمهورية الذي سيتعامل مع الرسوم التعليمية المعينة . 
7. وما تقام يجب وضعه في الاعتبار، بحيث بمكننا تدديد هل تكون الألوان داكنة أو قاتمة أو باردة أو ساخنة، وبالتالي تؤثر تأثير اليجابيا على المثاهد

\section{الألفة في اللون والثكل :}

إذا تحدثنا عن اللون فلابد أن يكون اللون مألوفا صريح العلاقة بين الرمــز

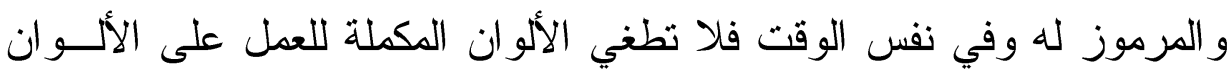

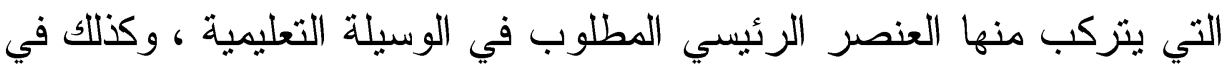
الثكل فقد وجد أن زاوية الرؤية الأثثد ألفة هي الزاوية الجانبية بالنسبة للأثنكال

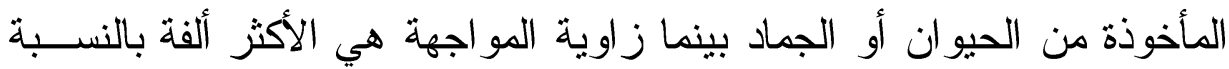

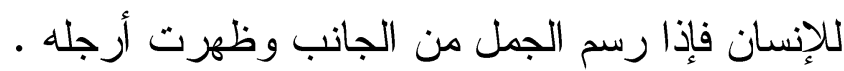

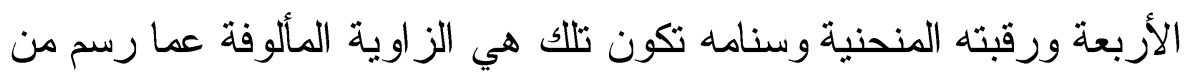

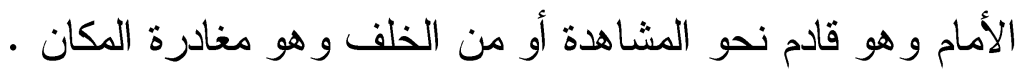
حيث أن هذه الزاوية تؤثر على الثنكل و الحجم و المساحة كما أنها غيره مــن

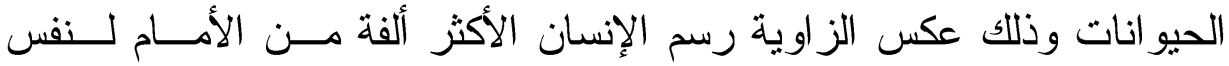

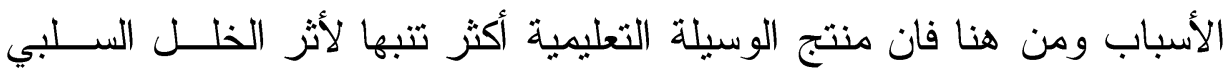

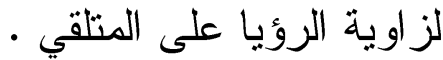

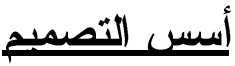

تعتبر أسس التصميم بمثابة الواقع البنائي لككونات الصورة التعليمية وهي أيضا النظم التي تحقق الثروط الو اجب مر اعاتها عند استخدام عناصر التصميم

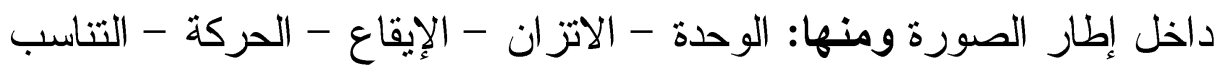

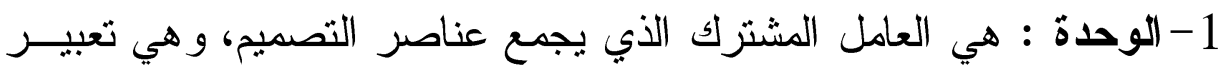

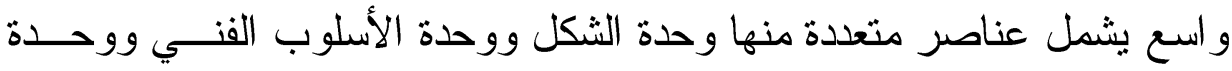
الفكرة ووحدة الهلف أو الغرض من الصورة المرسومة . 
وهذه العناصر جميعها هي التي تثير في الرائي الإحساس النهـائي بوحـدة

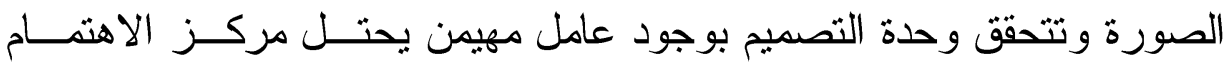
و عامل ثانوي يقوم بمثابة التابع للعامل المهيمن ليؤكده . 2-الاتزان : يعبر الاتزان عن الاستقرار و الثبات وهو الحالة التي تتعادل فيها

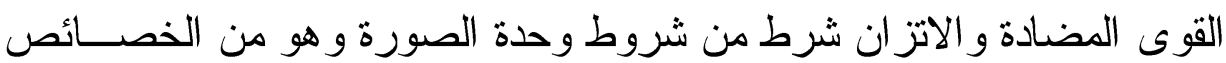
الأساسية الهامة في التصميم الناجح.

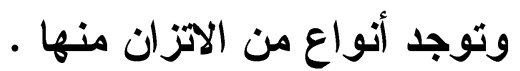

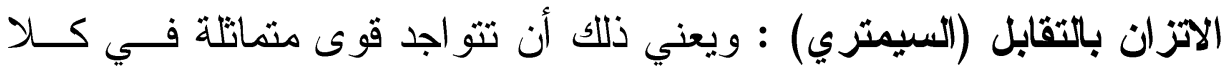

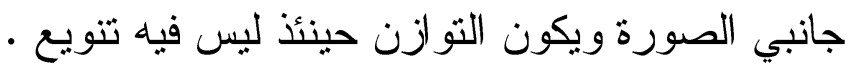

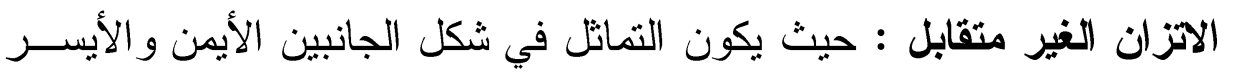

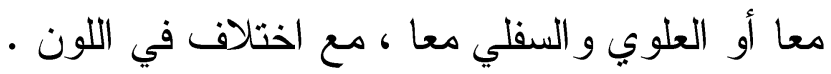

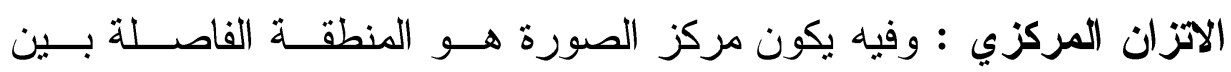
• عنصر ان متماثلان - وهناك نوع آخر من التوازن المستتر غير السيمتري لا يتفق فيه شـــل أون لون في أي من نصفي الصورة (العلوي و السفلي) أو (الأيمن و الأيسر) بل فئ لأليه

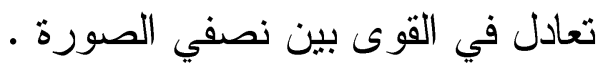
3- الحركة : تستمد الهيئة قيمتها الحركية إما حدودها الخطية الخارجية أو من لهن محاور ها الرئيسية التي تعمل على توجيه سير الحركة في اتجاه خاص ، وفئها

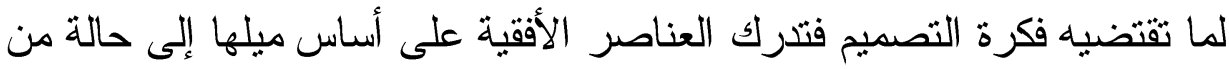

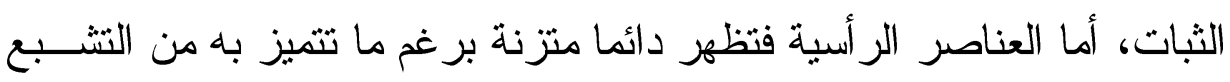

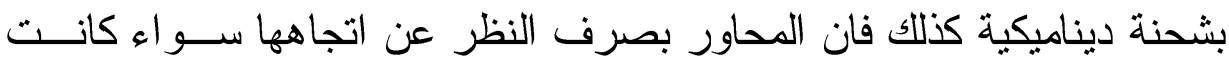

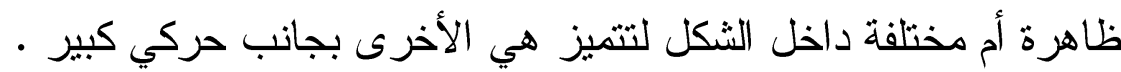
4-الإيقاع :الإيقاع هو التكرار المنتظم لعنصر أو مجموعة من العناصر على لهي

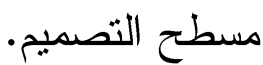


ويتكون الإيقاع من عنصرين أساسين هما : أ- الأثكال : وهي العنصر الإيجابي هن عندين

ب- الخلقية : و هي العنصر السلبي المسمى بالأرضيات المحيطة بالأشكال . ويتكون الإيقاع من تبادل هذين العنصرين متخذا واحد من الأشكال الآتية :

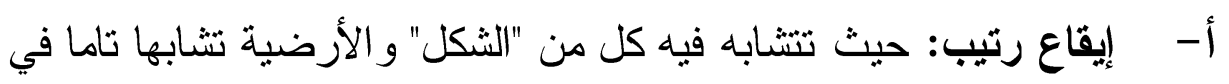

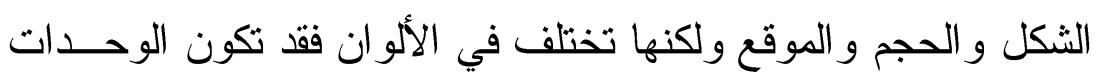

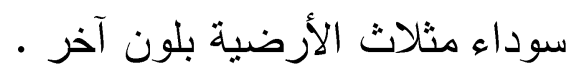

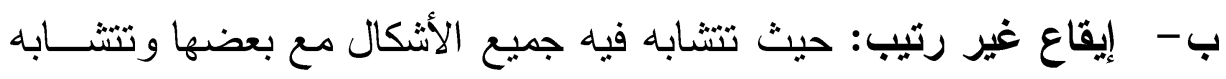

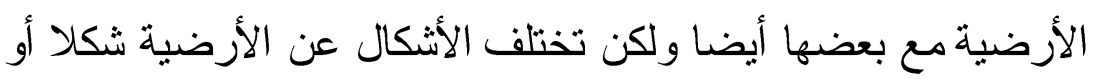

$$
\text { لونا أو حجما . الأسئ. }
$$

ت- إيقاع حر: حيث ينت توزيع الأشكال التز ام بتسلسل محدد ، ويختلف شكل

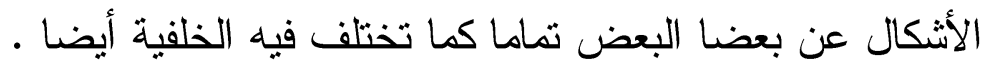
ث- - إيقاع متناقص : وفيه تتكرر بصورة مطردة في التناقض .

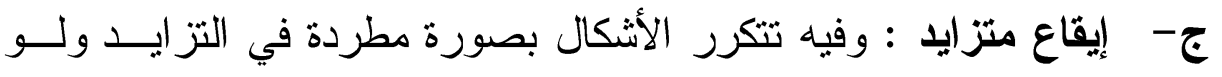

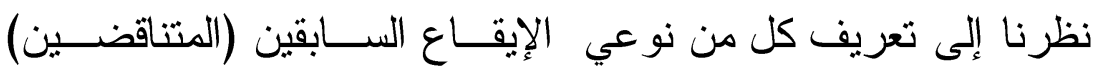

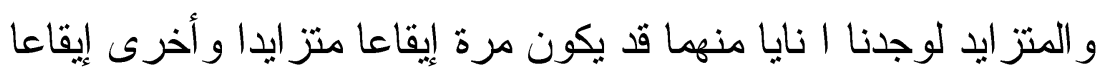
متتاقصا ويتوقف هذا الأمر على الجانب الذي ينظر منه الرائي ومثال ذلك ما نشاهده في صورة الأعمال التي وضعها الإنسان (مثل قضبان السكة الحديد و أعمدة التلغر اف و السلالم ... الخاخ)

التناسب : هو النسب الجمالية التي تضمن نوعا من قياس يمكن اتخاذه معيار يقاس من خلاله صلاحية الصور التعليمية أو عدم صلاحيتها . رابعا : توظيف أسس التصميم في إعداد الرسوم التعليمبة : إذا كانت الرسوم التعليمية كمثير ات مرئية تتكون هيئاتها من عناصر الفن 
المختلفة من أثنكال وخطوط و ألو ان وملابس فإنها قد تعتد في تصميم وصياغة

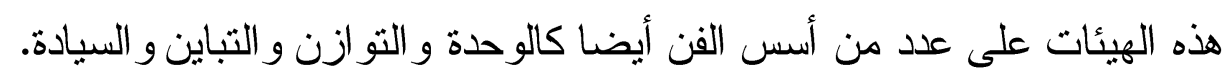

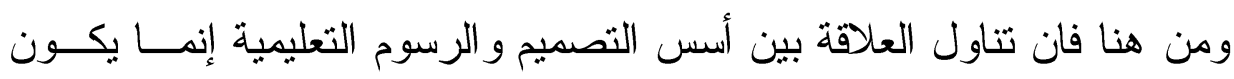

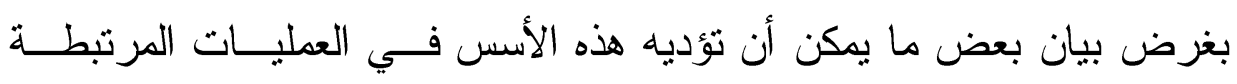
بتصميم تلك الرسوم . بان بعض بان الوحدة : الوحدة تتضمن تقرد معين في الثنكل المعروض فهي تعد أكثر أسس

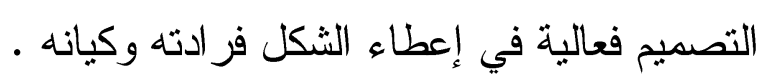

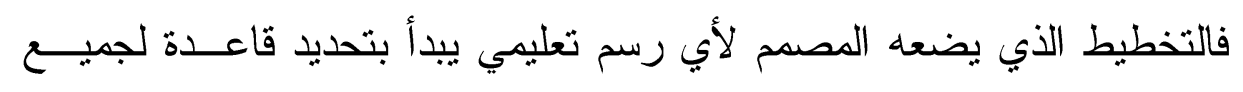

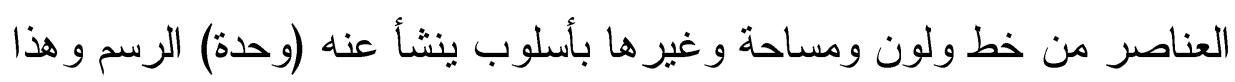

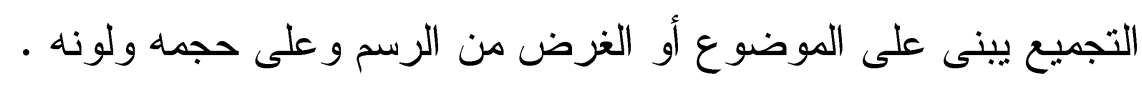

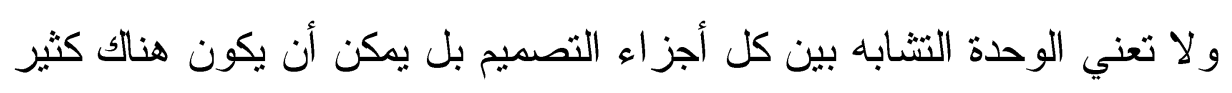

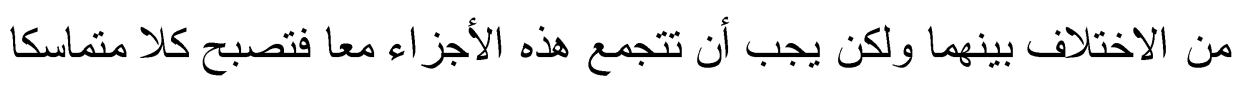

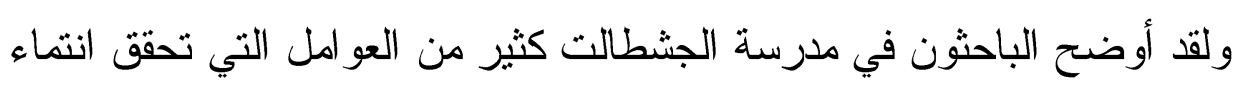

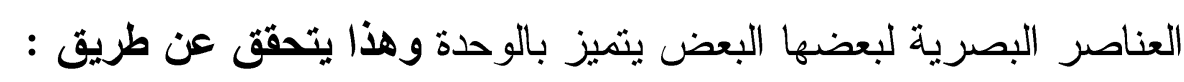

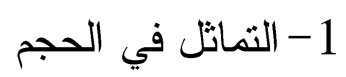

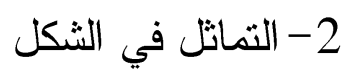
3- عن طريق التقارب 4- عن طريق اللون 5- 5ن طريق التوازي

عوامل ضعف وحدة الثكل بالصور التطليمية :

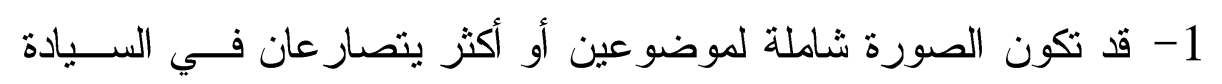

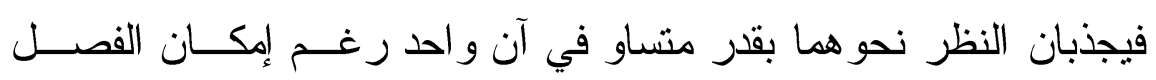

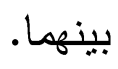


2- إذا حملت الصورة شكلين احدها واضح يدل عما يعبر عنه والثـاني مبهم فسوف يكون الثاني بأضعاف وحدة الثكل . 3- لو زاد عدد الأشكال المتجاورة المتباينة الألوان ويمكن التغلب على ذافعلى ذلك بإدخال خطوط جديدة في الصورة لتر ابط بين هذه الأشكال المتباينة . الطرق التي يمكن للمصمم التظلب عليها ومنها ما يلي :

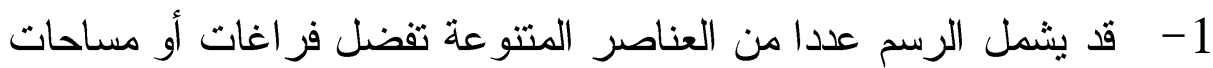
خالية مما يضعف وحدته ويمكن تفادي ذلك بالتقليل من هــــه الفر اغـــات وزيادة تقارب هذه العناصر جميعها داخل إطار خطي لان وضع خط حول الأجز اء المتنو عة غالبا ما يوجد بينها بطريقة كافية .

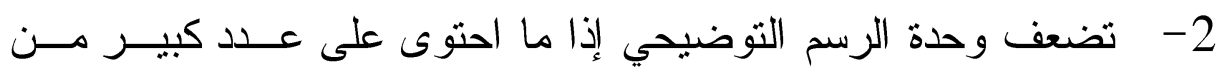

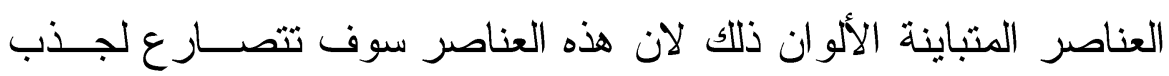

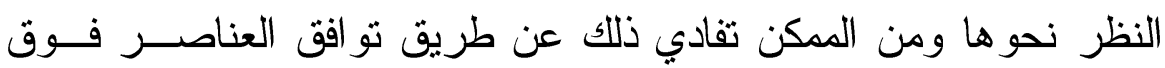

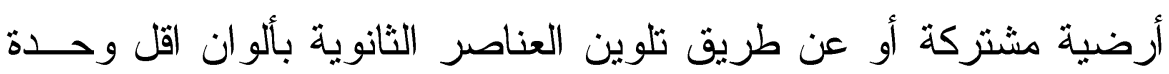
وتباينا والإبقاء فقط على تباين العنصر الرئيسي الأكثر أهمية . 3- قد يشتمل الرسم على بعض العناصر الو اضحة وبعض العناصر الغير

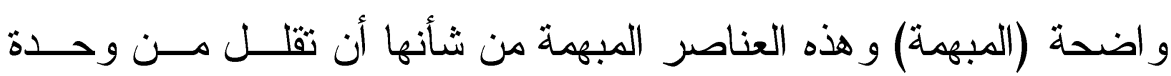

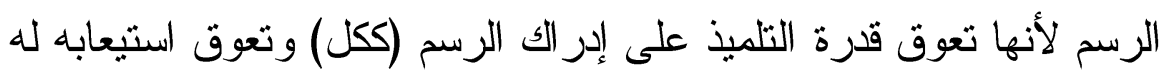

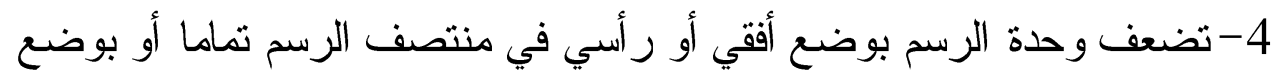

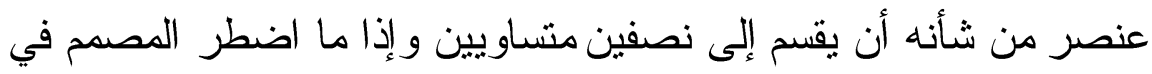

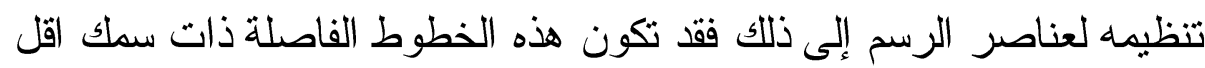
من إطار الرسم أو تكون على هيئة نقط أو شرط خطية قصيرة متجاورة في لئي

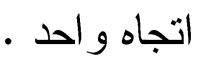

التوازن : الأشكال البصرية التي تعطي شعور ا بالتعادل يقال عنها أنها متو ازنة 
فالتو ازن يلعب دورا مؤثرا في إعطاء الإحساس بالر احة النفسية عند النظر إلى النى

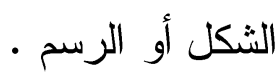
وغالبية الإثكال البصرية تتو ازن بو احدة من هاتين الطريقتين التقليديين :

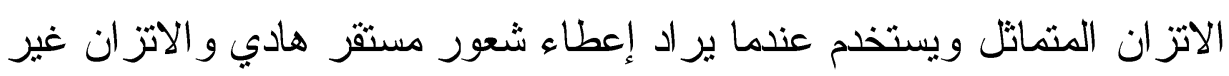
متماتل بعطي شعور ا بالحركة فهو نو عية (ديناميكية) .

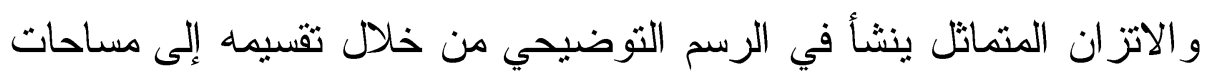

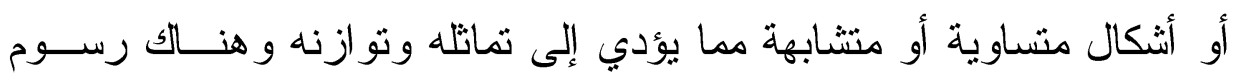

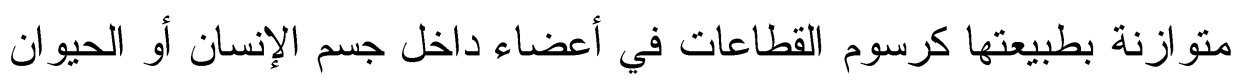

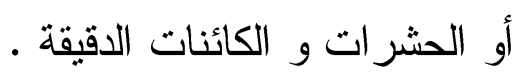
بينما الاتزان غير المتماتل لا يكون مماثلا لتانك التقسيمات البسيطة ففيه قد لا

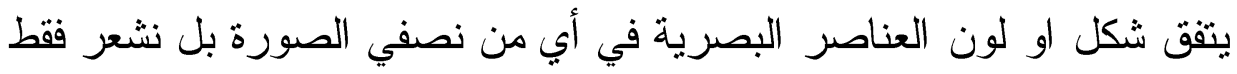

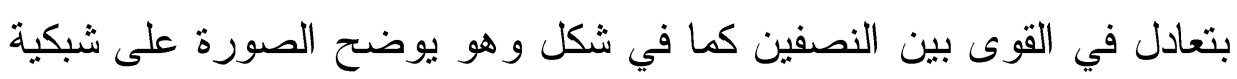

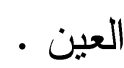

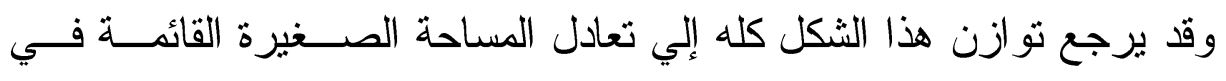

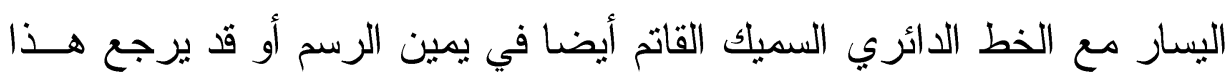

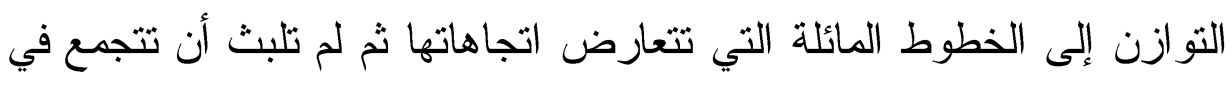

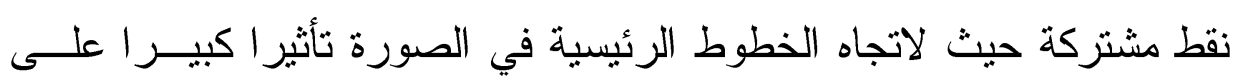

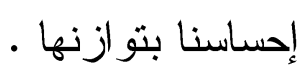

\section{ادرالك وتكوين الصورة الذهنية}

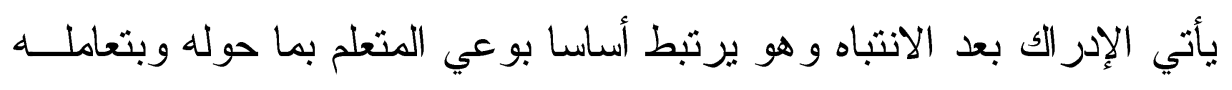

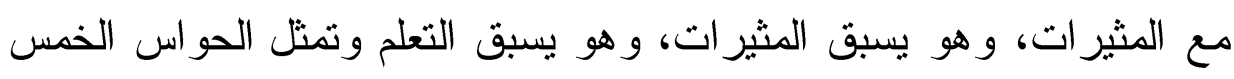

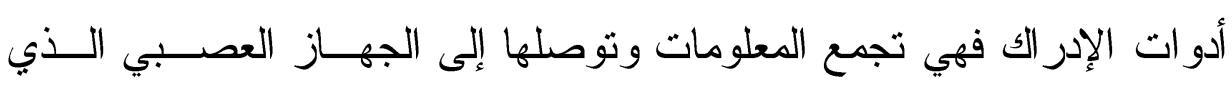

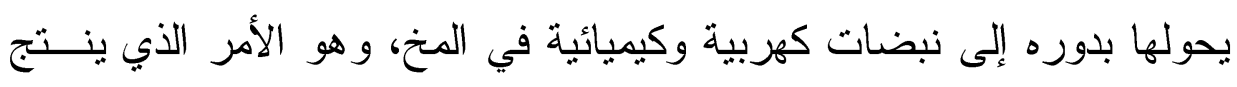


عنه الإدر الك الداخلي بالمثير، أي أن الإدراك يسبق الاتصــال وان الاتصــال بدوره يسبق التعليم.

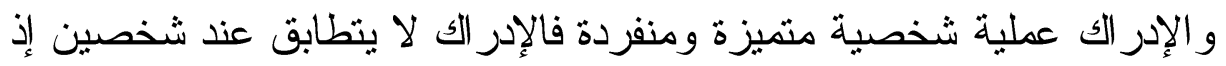

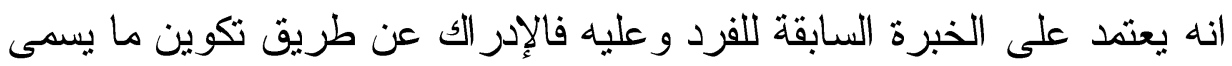
بالصورة الذهنية و هي الإحساسات التي يستعيدها العقل بعــــ انعـــام المــؤثز الأصلي الذي يستثير ها وتجدر الإشارة في هذا الصدد إلى أن الصورة الذهات الذهنية

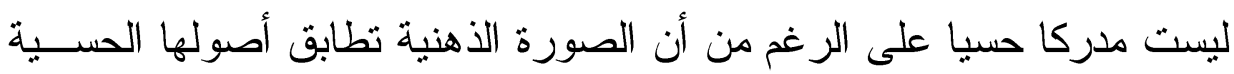

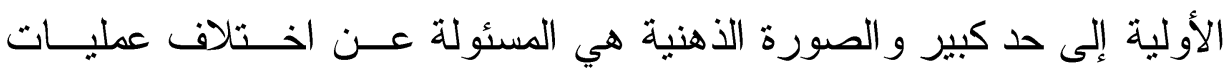

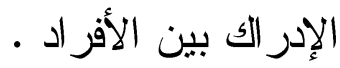

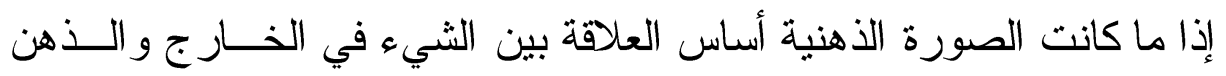
الإنساني فإن هذه الصورة أو المفهوم الذي يتكون في ذهن الإنسان يعد أساس

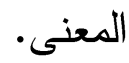

والفكرة القائلة : إن الإنسان يفكر من الخارج إلى الداخل تجعل الإنسان فـي

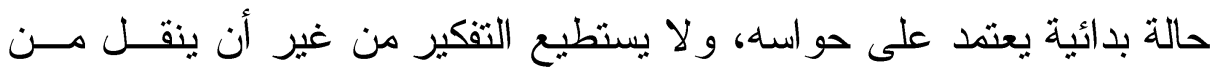
الخارج التصور ات التي تثير في نفسه صور يحلاها ويحاول مطابقتها مع الخار جو هذا التصور يجعل الإنسان متلقي، مهيته تحليل الصور الذهنية التي يتلقاها. و الحقيقة أن التصور ات التي تأتي من الخارج يشترك فيها كثير من البشر لكن لتهن

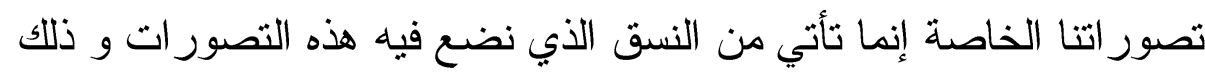

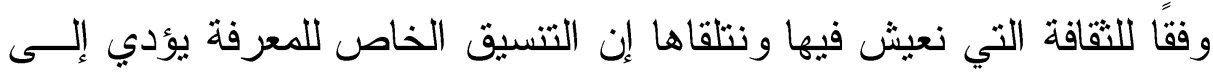

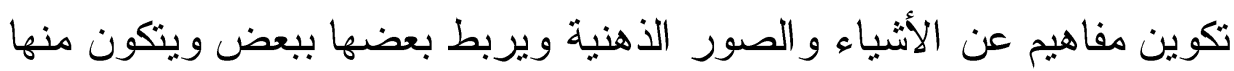
نسيج معرفي مغاير للأنساق المعرفية الاخري (جوديث، ونئ 1990). 
ولما كانت القدرة على تكوين الصورة الذهنية استعدادا طبيعيا عند الإنسان فان

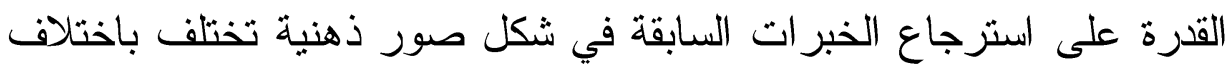
الأفر اد . الأ.

كما أن الفرد الو احد قد يختلف من حيث قدرته على تكوين الصور الذهنيــة للإحساسات المختلفة فهنالك من يسهل عليه استرجاع الصور الذهنية البصرية

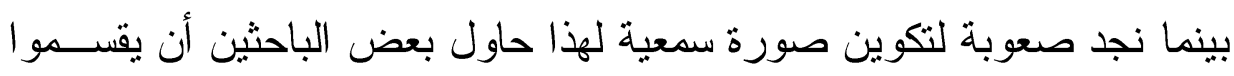

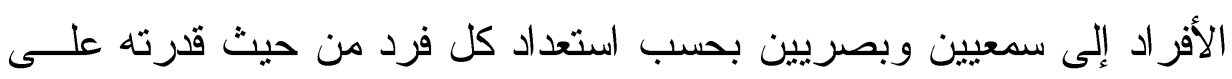
استرجاع تجاربه السابقة في شكل صورة ذهنية بصرية وسمعية وتجدر الإشارة

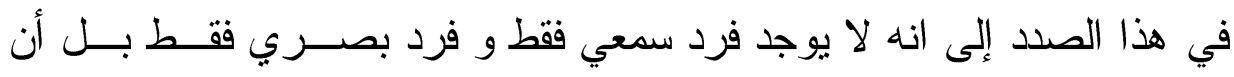

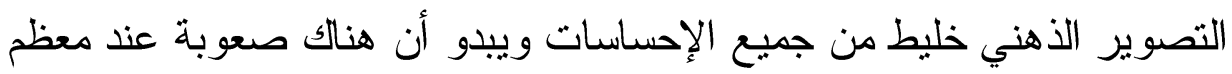

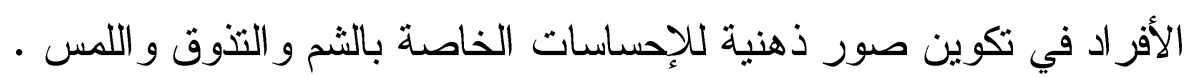

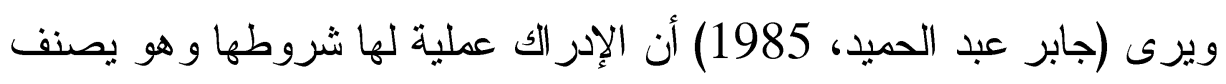

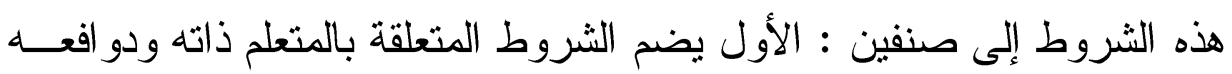

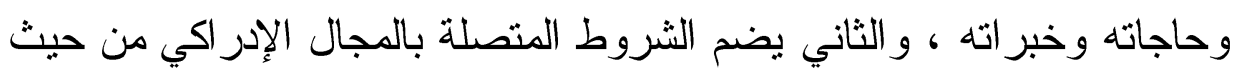

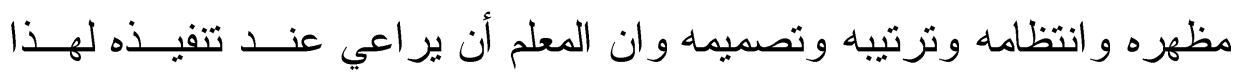
الموقف الثروط الخاصة بالمتعلم من استعداد وميل وخبرة ، و الثروط ونئه المتصلة

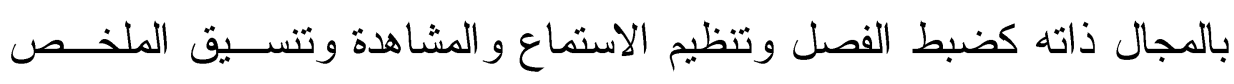
السبوري وحسن استخدام الوسائل التعليمية . ويرتبط الإدر الك ببساطة بالمثير ات المعروضة و أسلوب ترتيبها وتنظيمها وكلما

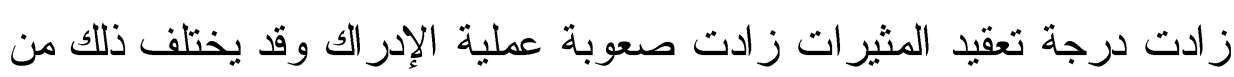

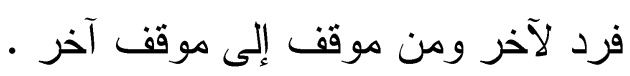

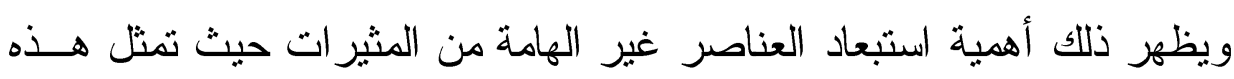
العناصر عو امل شوشرة بالنسبة للمتعلم كما سبقت الإشارة . 
كما يرتبط الإدر اج بالنضـج العقلي حيث أن درجة تقبل المثيــرات المعقــدة

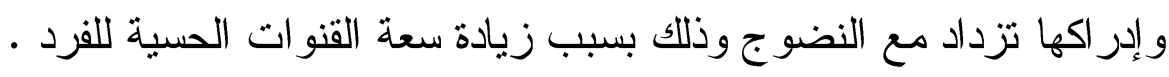

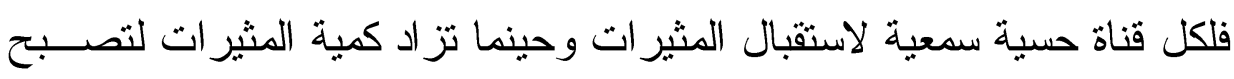

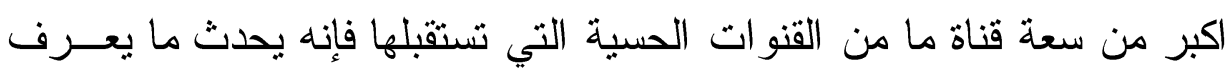
بالتقنية و التبديل أو الاختبار فحينما تزداد سرعة من حديث المعلم مثلا فإنه بحدث

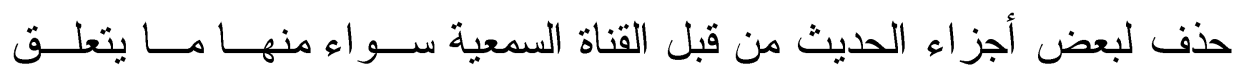

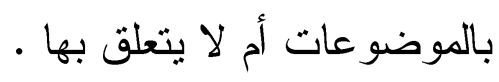
وفي حالة المادة السعية البصرية فانه تحدث عملية التبادل حيث يتركز انتباه

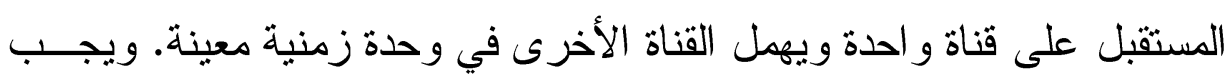

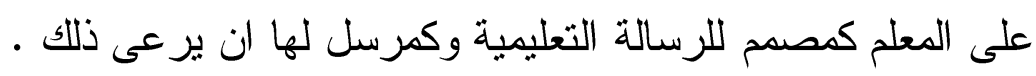

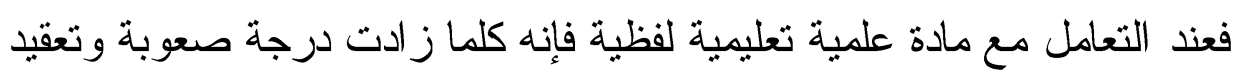

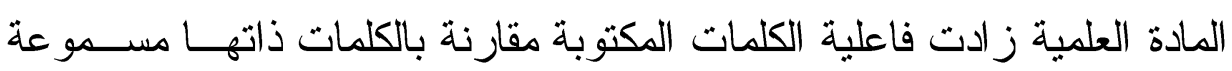

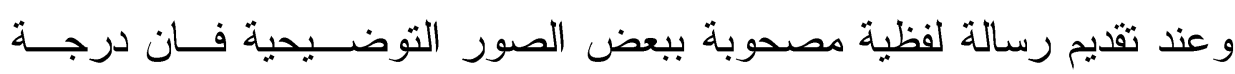

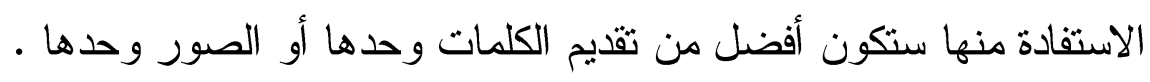
تحفيز الاوا(فع الادة من أوضح (على عبد المنعم، 1996)أهمية الدو افع و هو يرى أن نقطة البداية في

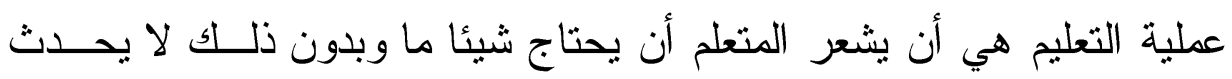

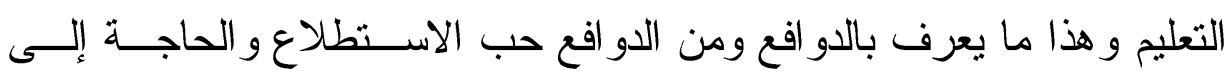

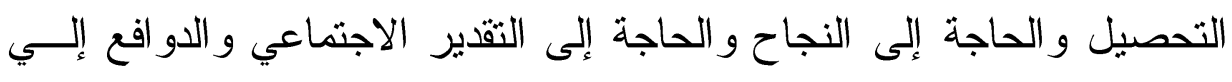

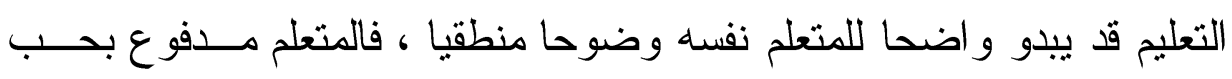

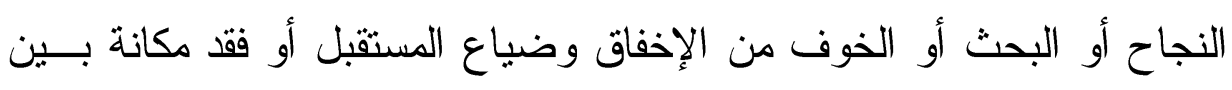

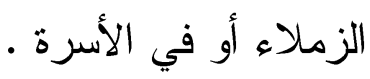
ومن الملاحظ أن الأجززة و الأدوات و المو اد التعليمية لا تكون الــدو افع فــي

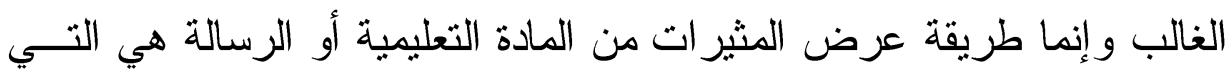


تحقق ذلك ويجب أن تصاغ الرسالة بما يتناسب مع حاجات المتعلم وبطريقــة

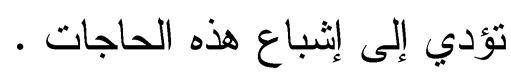

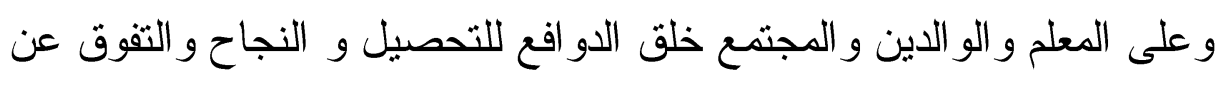

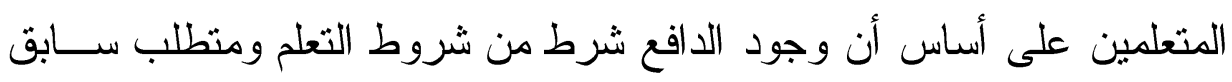

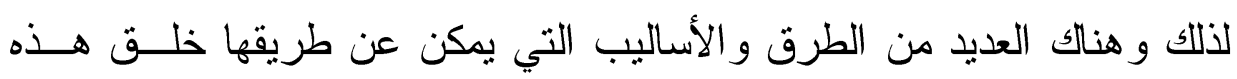

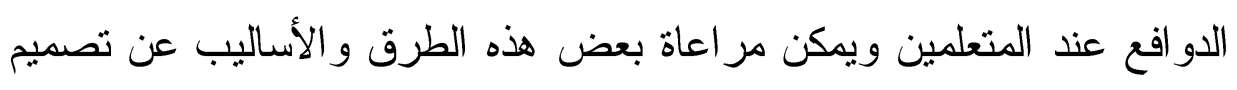

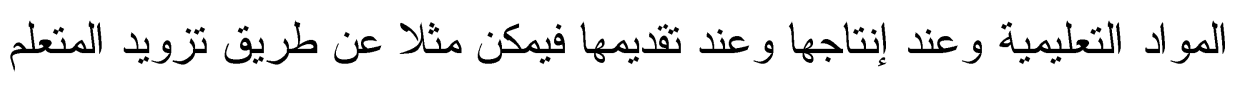

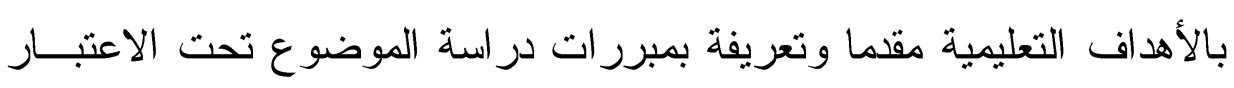

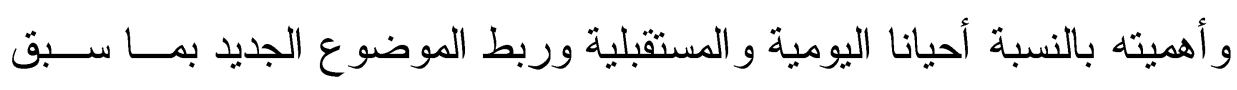
تعلمه.

ويمكن عن طريق ذللك خلق بعض الدو افع لاى المتعلمين للإقبال على عملية

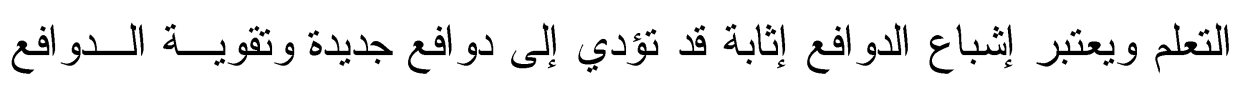

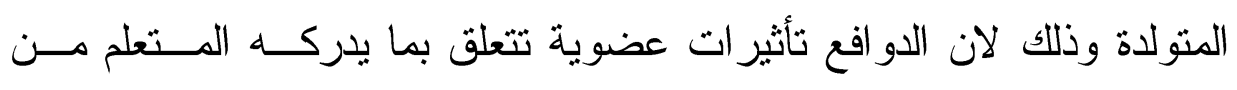

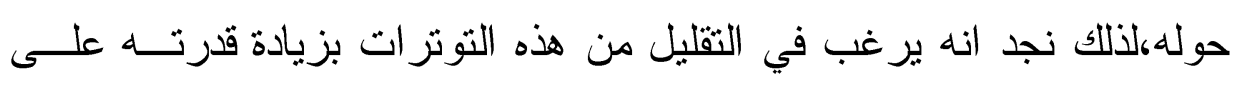

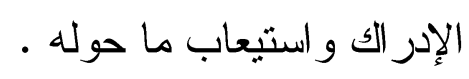

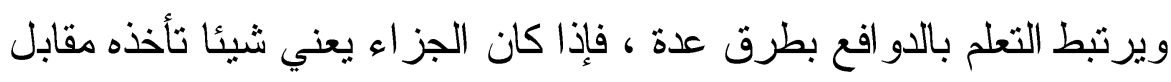

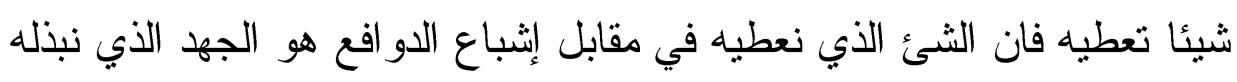

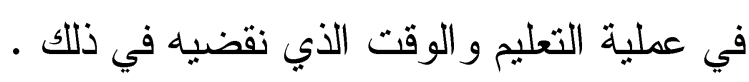

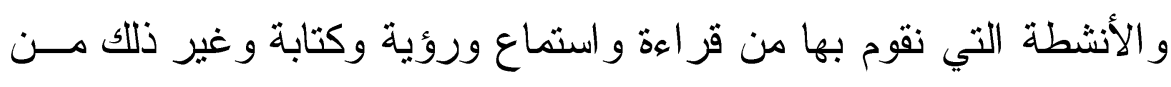

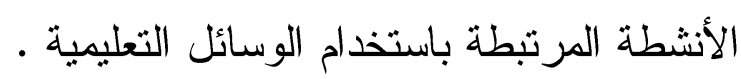
خصائص الإدراك البصري ومبادئه :

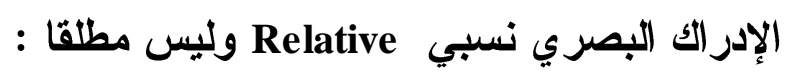

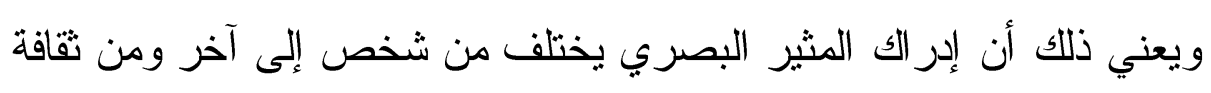

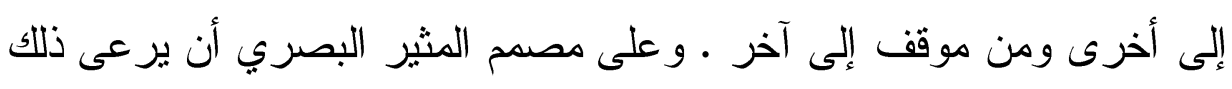
doi : 10.12816/0001052 
و عليه أن يزور المثير البصري ببعض الدلائل التي يمكن أن توجــهـ المتلقـي

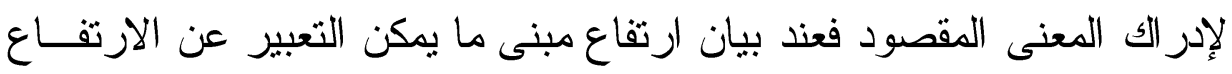

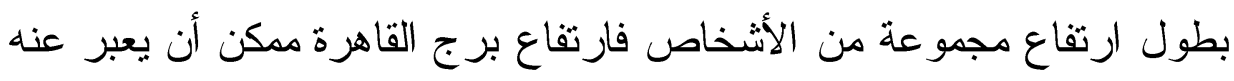

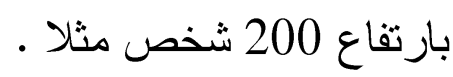

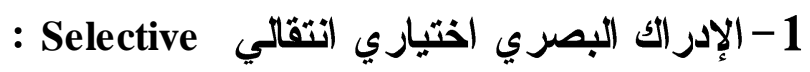

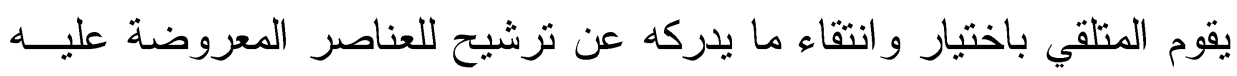
ولذلك يجب على المصمم ان ير اعى ذلك عن طريق تقليل

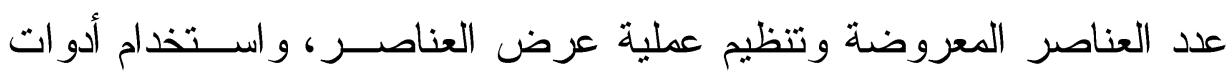

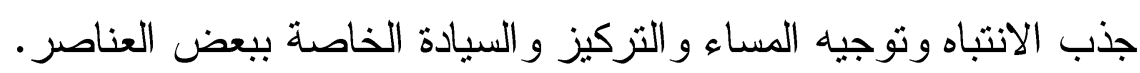

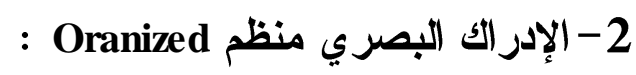

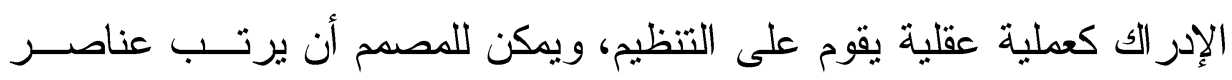
المثير البصري بصورة تساعد المتلقي على الإدر الك بفاعلية وكفاءة وهنا تظهر

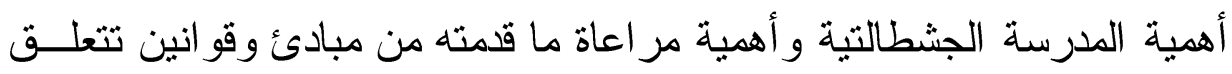
بنظم المجال الإدر اكي ولعل مبدأ الشكل و الأرضية يعد هاما عند اعتبار كيفية تنظيم عناصر المثير البصري .

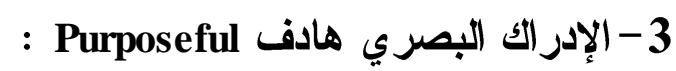
يقوم المتلقي بعملية الإدر الك لإشباع حاجاته و استجابته لدو افعه و لتحقيــق أهداف محدة ويمكن للمصمم ان ير اعى ذلك عند تفكيره في إجر اءات التصميم حيث يجب أن يضع خصائص المتلقي وحاجاته ودو افعه في الاعتبار حتى يزيد

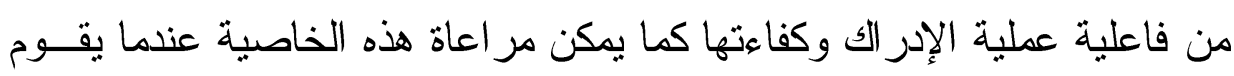

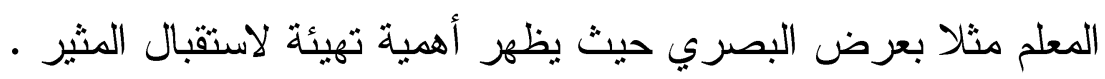
بعض برامج التصميم للصور الجرافيكية : AAA logo 20082.10 برنامج برجم 
- برنامج صانع شعارات يحتوي البرنامج على أكثر من 2000 تصميم جاهز

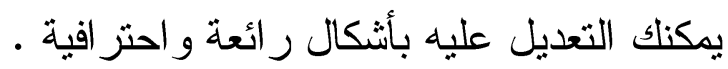

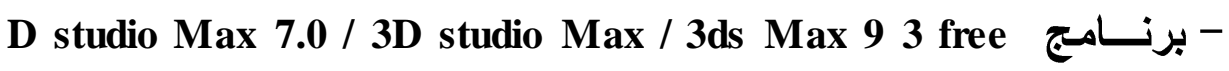
Download - برنامج 3 D studio max 3 دي دي استيليو ماكس جميع إصدار اته هنا مثل Ds Max 6 /3ds Max 9 free Download 3 التصميم الثلاثي الأبعاد وتصميم الأفلام و اقصد أفلام الكرتون و غيرها البرنامج ذو امكانيات فريدة في هذا المجال . - برنامج الفوتوشوب يحتوي على العديد من الإضافات و هذا إصدار يعد احتز افي بما يحويه من

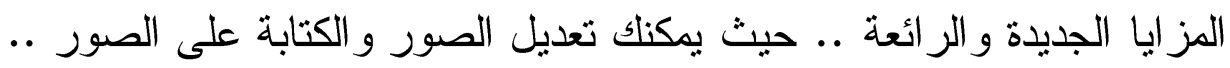

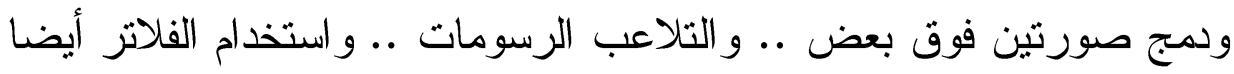

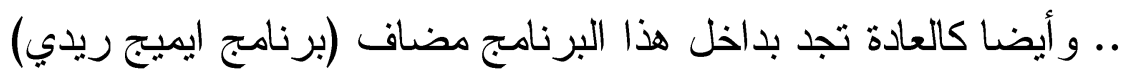
Adobe Image ready CS Autodesk 3ds max 2009 / برنامج 2008 الذهول و الإبداع و التميز في التصميم الثثلثي الأبعاد برنامج يعمل الكثير من لكن التأثنير ات البصرية والصور المتحركة . Adobe Photoshop lightroom 2.0 Beta برنامج يقوم هذا البرنامج بتوضيح وتنقية الصور و إخر اجها على أفضــل شــــل بإمكانك التحكم بالضوء ومدى سطوعه ، و التقتيم و التقتيح ، وتغييـــر ألـــوان

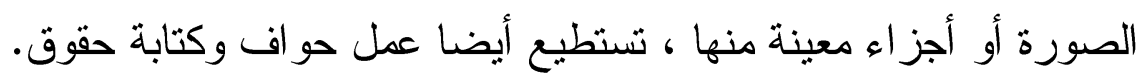
- برنامج تصميم البنرات 1.3.3 - Banner effect - برنامج تصميم البنرات Banner effect برنامج يسمح للك بتصميم البنــر ات

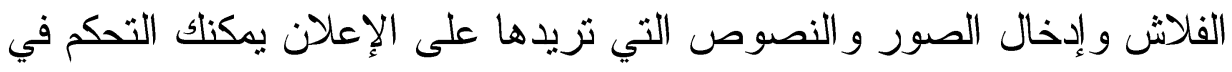
حجم البنر ليتناسب ول.... (1) doi : 10.12816/0001052 208 
- برنامج تصميم الكروت 11.20.55 -

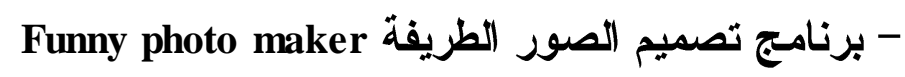
funny photo برنامج تصميم الصور الطريفة ، برنامج فاني فوتو ميكـر maker و الطريفة حيث يتضمن تأثير ات فريدة .

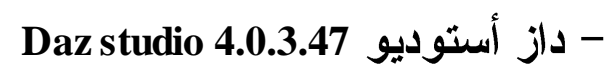
- داز أستوديو برنامج Daz studio تصميم المجسمات ثلاثية الأبعاد يقوم هذا البرنامج بعمل نماذج ثلاثية الأبعاد بأسلوب احتر افي ، يمكنك من تنفيذ مشاهد متعددة ومتتابعة ....

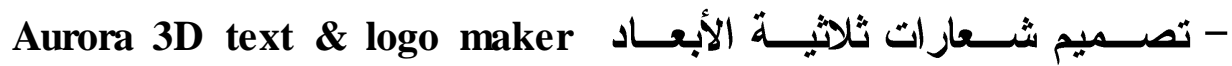
12.05251308

يتيح للك هذا البرنامج بتصميم الثعار ات و النصوص المجسمة أو ثلاثيــة

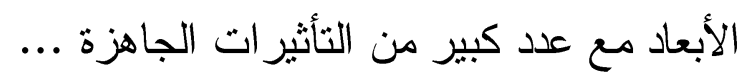

تصميم الأشكال المجسمة برنامج يتيح للك تصميم النصوص و الأشكال المجمة ثلاثية الأبعاد يقام نماذج

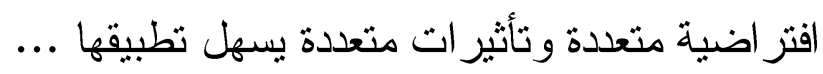

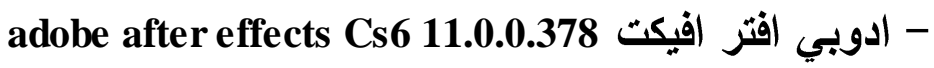
- ادوبي افتز افيكت adobe after effects Cs6 تطبيق مشهور مـن شـركة ادوبي يساعدك على تصميم الايموشن و الجر افيكس الخاص بالصور و الانيميشن الصور المتحركة ويمكن أن يتم تصدير ها ل...

Adobe photoshop cs6 ادوبي فوتوشوب 13 - 13.0 برنامج ادوبي فوتوشوب 13 Adobe photoshop cs6 13.0 إحدى أثــــر

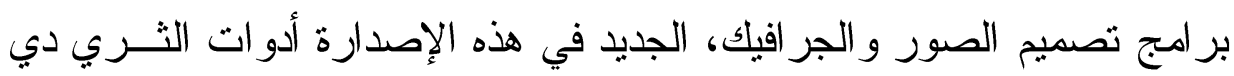
التي تجعلك توصل أفكار إبداعية بأسلوب ... 
Twistedbrush pro studio 18.00 تعديل الصور

برنامج متكامل لتعديل الصور يحتوي على أنماط متعددة للفرشــاة تبــــغ

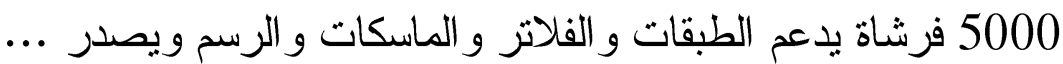
Microsoft Image Composite Edit 1.4.2 تركيب الصور من ميكروسوفت

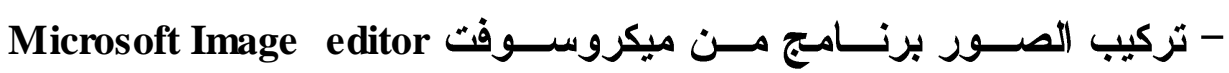
Composite يعمل هذا البرنامج على تحرير الصور وتعديلها وتأليف وتركيب الصــور

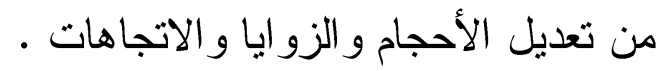

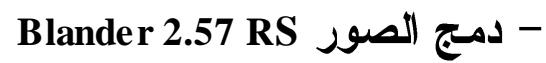
دمج الصور Blander برنامج بليندر يقدم بيئة عملية وسهلة لدمج الصور

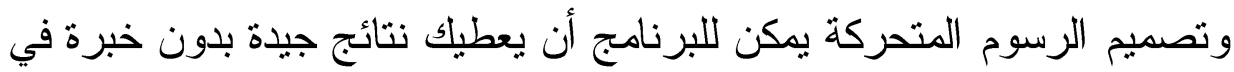

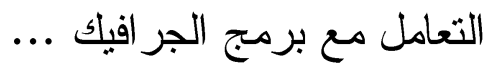
- محرر الصور مos free photo editor محرر الصور Pos free photo editor برنامج تحرير الصور برنامج سهل وبسيط لتحرير الصور وتعديل الصور ويمكنك طباعة الصور وحفظها بـأكثر من صيغة

- محرر الصور Graphic Workshop professional 3.0a.30 - مدئ - محسـرر الصـــور Graphic Workshop professional تحريـــر الصـــور

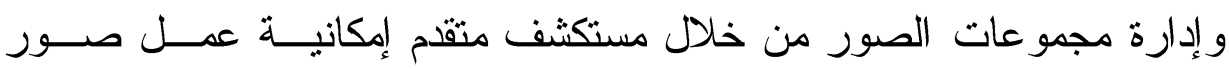

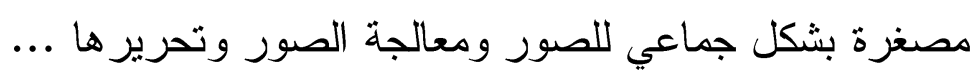

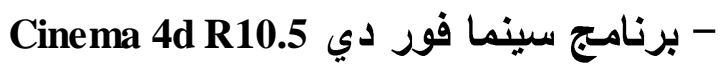

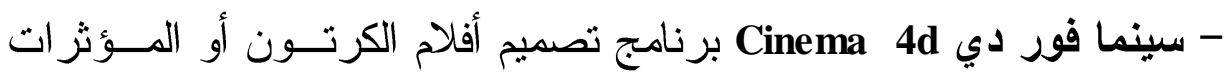
و المشاهد السينمائية لأفلام الكرتون سينما فور دي Cinema 4d برنامج تصميم

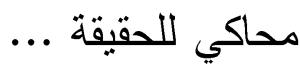

Paint.net 4.50.3480.39777 alpha مصم ومحرر الصور doi : 10.12816/0001052 
مصمم و محرر الصور Paint.net برنامج مميز محرر ومصمم الصــور

مفتوح المصدر يعمل على تحرير الصور وتصميم الصور و إضافة المؤثرات

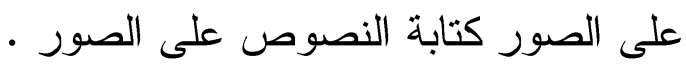

Picture collage maker 1.7.8 build 998 تصميم البوم صور تصميم البوم صور برنامج Picture collage maker برنامج يقـوم بعدــل البوم صور لصور العائلة أو الأصدقاء ويساعدك على تجميعها في البوم واحد ويوفر للك العديد من الإطار ات و ...

Fun morph 4.49 خدع سينمائية برنامج خدع سينمائية Fun morph أداة جيدة تقوم بعمل تداخل الصور مع سعائم

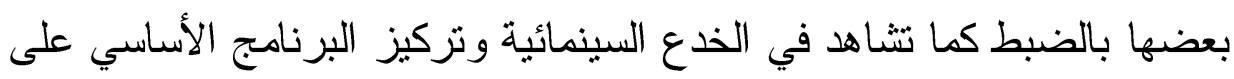

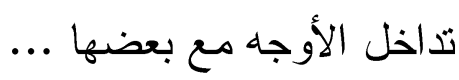

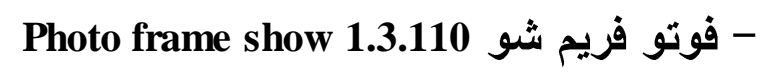
برنامج Photo frame show برنامج ممتاز لمن يرغب في في إضافة إطــار ات

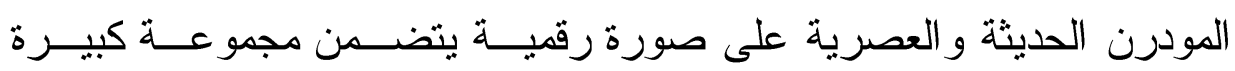
الإطار ات المختلفة ويعمل على تصدير ل....

- تصميم وإنشاء الرسوم البيانية 8.122007 برنامج Smart draw يساعدك على تصميم و إنشاء الرسوم البيانية بأسلوب

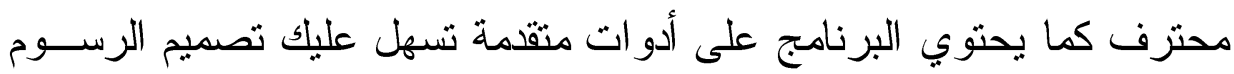
وكذلك يحتوي على 1500 نموذج ... - بوينت شوب محرر الصور 11.11 Paint shop pro برنامج Paint shop pro محرر صور مشهور وسهل الاستخدام يعمل على بلى

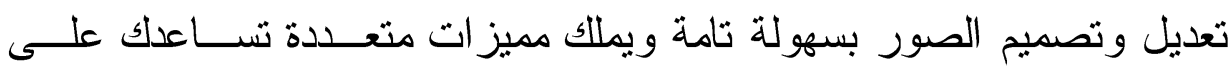

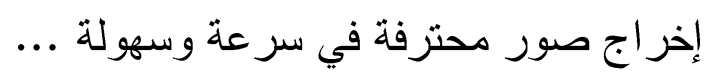

- تصميم العلامة المائية 6hoto watermark professional 6.2.0. 
برنامج Photo watermark أداة جيدة لتصميج و إضافة العلامة المائية على ، ألى

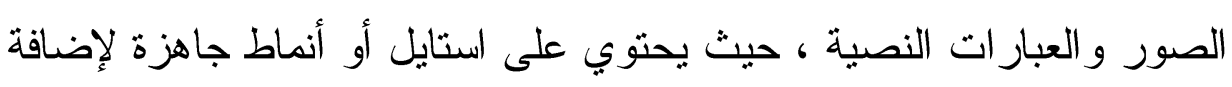
العلامة المائية على الصور ل...

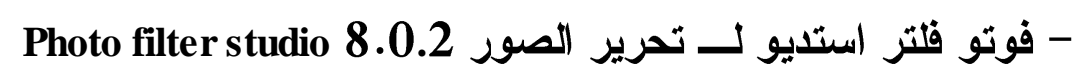

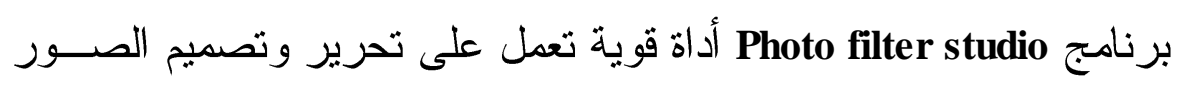
الفوتوغر افية ويتميز البرنامج باحتو ائه على مجمو عة كبيرة من عن الفلتر المميزة و الفعالة .

- تحرير وتصميم الصور Artizen HDR 2.4.3 برنامج تصميم صور Artizen HDR برنامج إدارة وتصميم الصور أداة

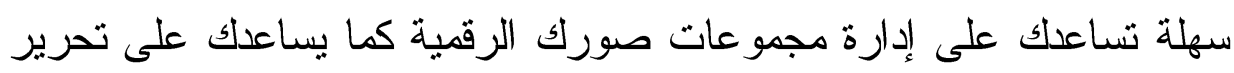

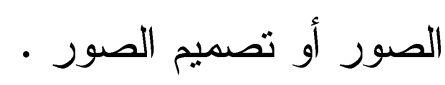

- برنامج تصميم ورسم يدوي

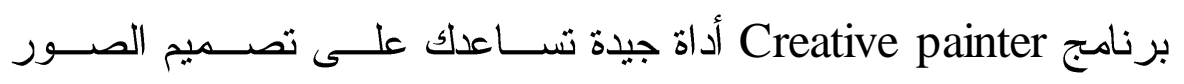

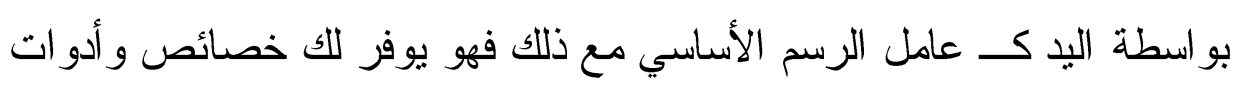

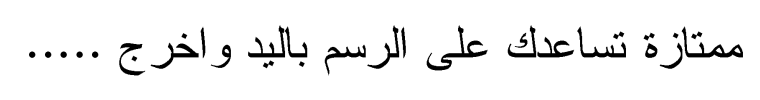
Belltech greeting card designer تصميم البطاقات والكروت الاكترونية الكانية v4.00

- فوتو فلتر تحرير الصور 6hoto filter 6.2.6 -

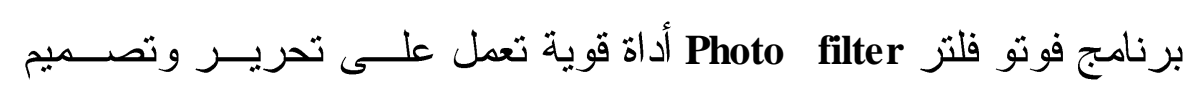
الصور الفوتو غر افية يتميز البرنامج باحتو ائه على مجمو عة كبيرة من الفلتـر فئر

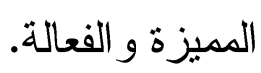

فوتو امبكت 12.0 برنامج التصميم Ulead photo impact يتميز هذا البرنامج بالعديد مسن

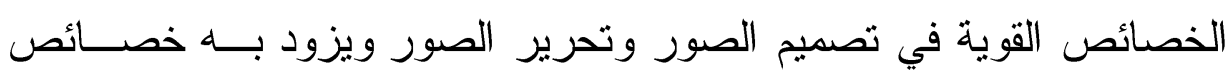
تصميم أنماط الصفحات ... doi : 10.12816/0001052 
Corel draw graphics suite x3 13.0.0.576 برنامج كورل درو جرافيك -

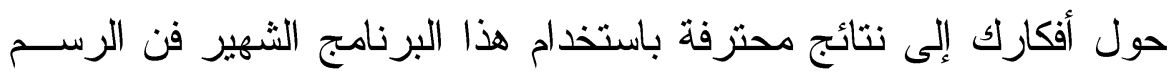
البياني ، زود البرنامج بأدو ات متقدمة وتحسينات ...

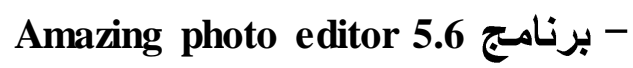
المحرر الفوتو غر افي المدهش لتحرير الصور ببر اعة وسهل الاســتعمال ،

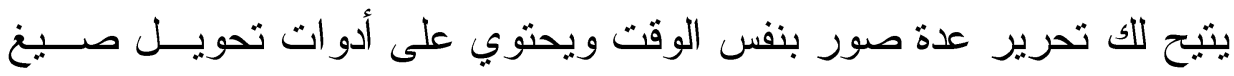
الصور المتعددة ....

Picture windows pro 4.0 برنامج -

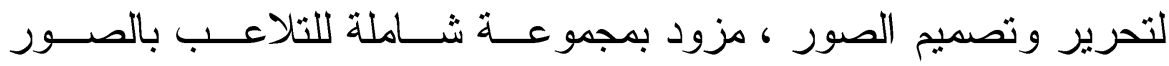
الفوتو غر افية صمم خصيصا للمصورين حيث يضع للك السيطرة على تشئكيل وتحرير الصور وطباعتها ...

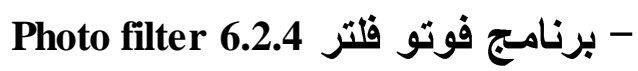

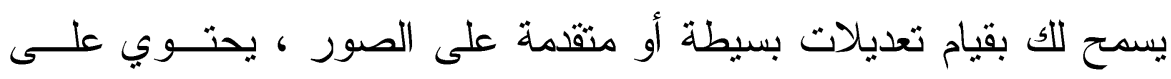

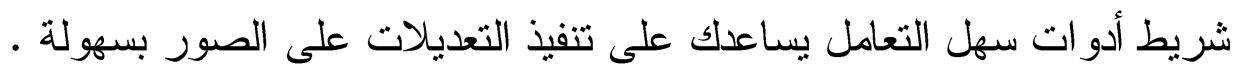
- برنامج 2.5.2 -

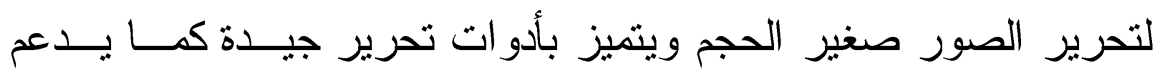
خاصية التقاط صور من سطح المكتب . أداة ممتازة لإضافة الإطار ات للصور تحتوي على أكثر من 300 إطــار

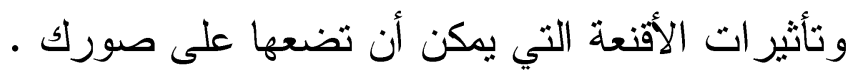
Ulead photo express v6 برنامج فونت اكسبريس من روائع برامج تحرير و إنشاء وتصميم الصورة برنامج

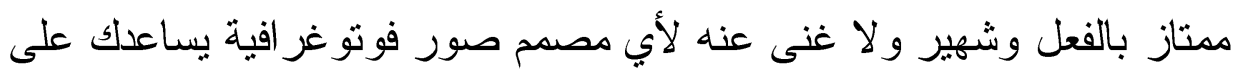
التصميم. 
Photo interface assistant v1.8 برنامج -

أداة تكميلية لبرنامج photo shop حيث يوفر للك مساحة أكثر بالثاشـــة ويتحكم بالنو افذ و التول بار ويعطيك شكل أسرع في انجاز مهامــك بالبرنــامج دون أي عقبات .

- برنامج فوتو فلتر استديو يعمل على تحرير الصور وذلك بطرق بسيطة جدا وسهلة وإحداها عـن لـن

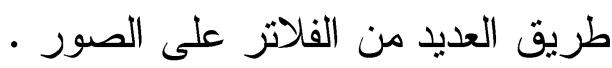
Photomatix pro v2.0.5 final برنامج برنامج ممتاز في تحرير الصور يعمل على تقتيح الصور وعمل قياسات

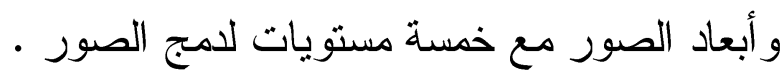

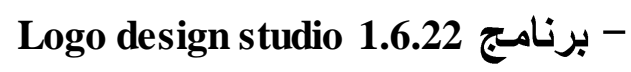
استديو تصميم الثعار ات برنامج جيد لتصميم وخلق الشعار ات الاحتر افية

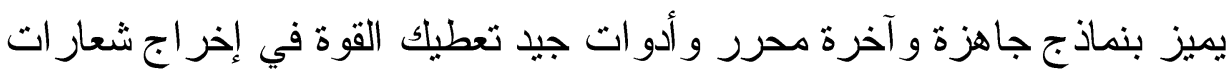
- برنامج 1.5 Photo-colorizer هذا البرنامج يعمل على تلوين الصور الأبيض و الأسود ، فإذا كان لــديك

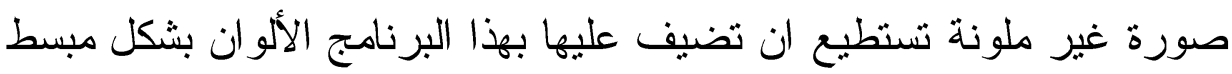
وسهل للغاية .

Adobe Illustrator CS2 برنامج أداة ممتازة من إنتاج شركة adobe لصناعة الشعار ات و الرسوم ، يعتمد

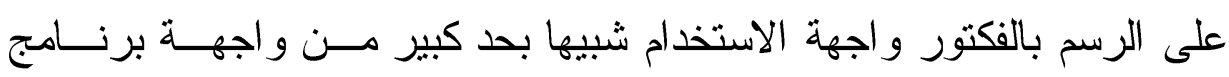
photoshop

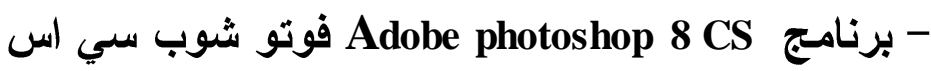

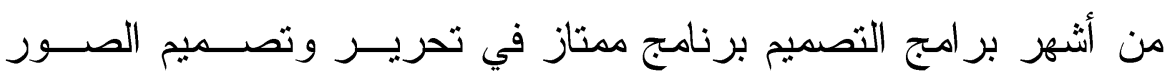
وصفحات الويب ، نسخة مخصصة للشرق الأوسط داعمة للعربية حيث تستطيع الكتابة باللغة . 
(لنتائمج

1.وضوح فاعلية استخدام التقنيات الجر افيكية المعتمدة على الإدر الك البصري

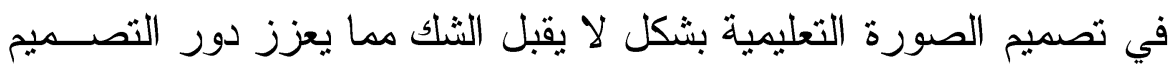
الجر افيكي في انتاج الصورة التعليمية. 2.دور الثقنيات الجر افيكية المعتمدة على الإدر الك البصري في إنجاح العملية

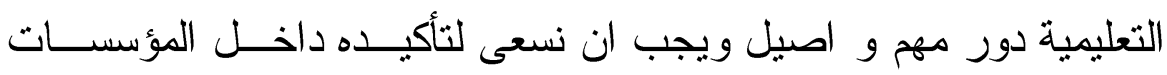
التعليمية المختلفة.

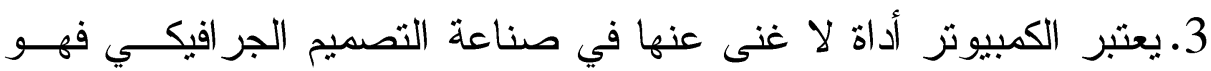
يعطي الثكلالنهائي للصورة التي كانت في ذهن المصدم الجر افيكي ويـتـ استخدامها مباشرة في العملية التعليمية.

\section{التيصبات:}

1 - ضرورة اهتمام المؤسسات التعليمية و التربوية بتظيم الورش و المعارض

$$
\text { للتعريف بفن الجر افيك. }
$$

ץ- التركيز على فنون الجر افيك في مدارسنا وذلك لما يتضمنه هذا الفن مسن مجالات و أنشطة متعددة مثل: الرسم و الطباعة الفنية و الرسوم المتحركة و الكمبيوجر افيك وفنون الكتاب وفنون الدعاية و الإعلان وفنون الوسائط المتعددة.

ب- إقامة الندو ات و المؤتمر ات التي تتناول أهمية فن الجر افيك فـــي الفـــــن و الإعلام و التربية.

ع - تزويد المؤسسات التعليمية و التـريبية بالأجززة التقنية الحديثة لملاحقـــة النطور الهائل في مجال فنون الجر افيك و الطباعة الفنية بشكل عام. 5- دعم المكتبات المحلية و العربية بالكتب المتخصصة بفن الجر افيك ســـواء

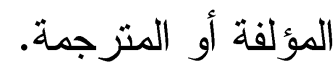




\section{المبر الميع}

أولاًا : العرلجيع العربية

1- احمد إبر اهيم قنديل (2006) : التدريس بالتكنولوجيا الحديثــة ، ط1، القــاهرة :

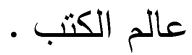

2- احمد حامد منصور (1992) : المدخل إلى تكنولوجيا التعليم ، سلسلة تكنولوجيــا.

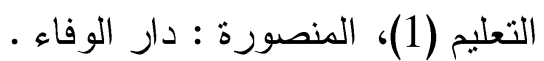

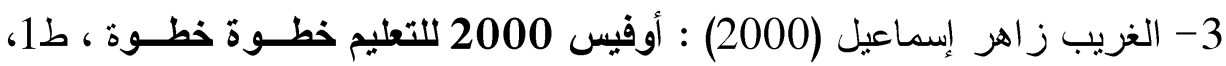
المنصورة : دار الوفاء.

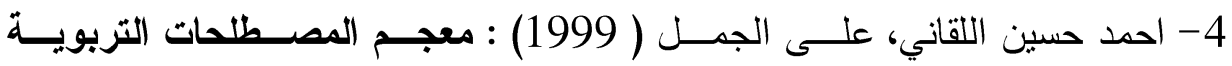

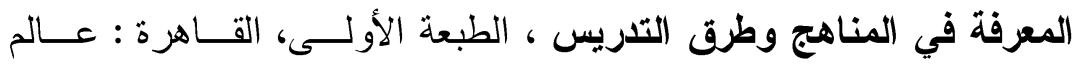
الكتب . الكعر في

5- الثحات سعد محمد عتمان (2002) : فاعليــة اســتذام تكنولوجيــا الوســائط

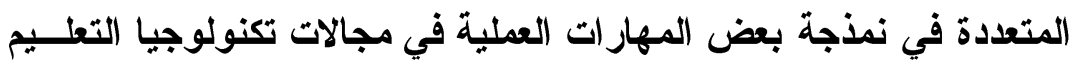

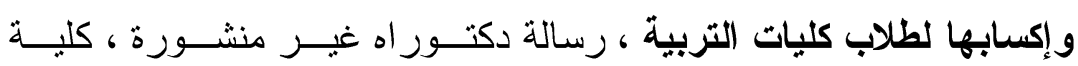
التزبية بدمياط ، جامعة المنصورة .

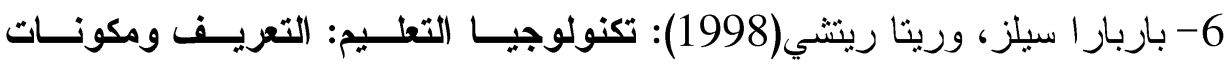

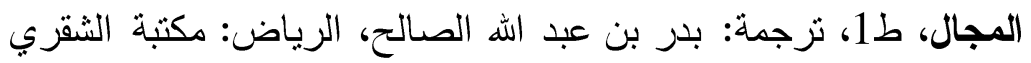

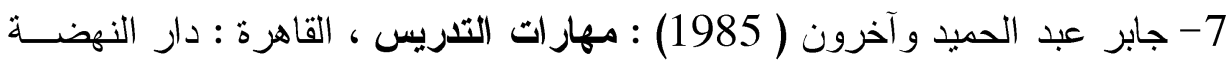

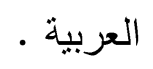

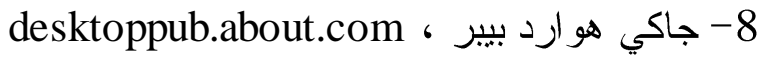

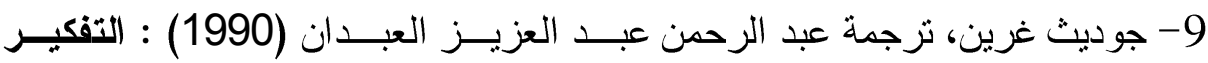

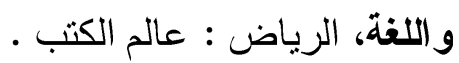

10- ديريك رونتري (1984) : تكنولوجيا التربية في تطوير المــهـج ، نرجمــة :

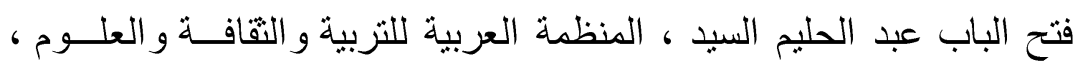
المركز العربي للتقنيات التربوية .

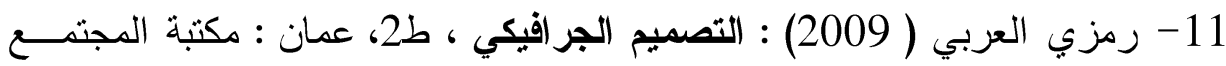
العربي • - مبري 
12 ز اهر احمد (1997) : تكنولوجيا التعليم ( تصميم وإنتاج الوسائل التعليمية) ، الجزء الثاني ، الطبعة الأولى، القاهرة : المكتبة الأكاديمية

13- ضياء زاهر ، كمال يوسف اسكندر (1984) : التخطيط لمستقبل التكنولوجيـا

التعليمية في النظام التربوي ، سلسلة معالم تربوية ، القــاهرة ، مؤسســـة

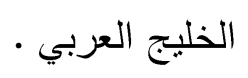

14- عبد الرحمن إبر اهيم الشاعر ، إمام محمد إمــام (1986) : مفــاهيم أساسـية

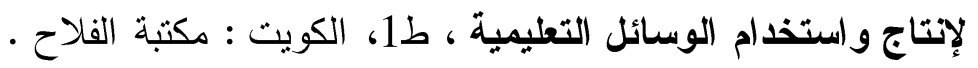

15- علي محمد عبد المنعم (1996) : "المستحدثات التكنولوجية في مجال التعليم -

طبيعتها وخصائصها " ، مجلة تكنولوجيــا التعلـيم - سلسـلـة در اســات

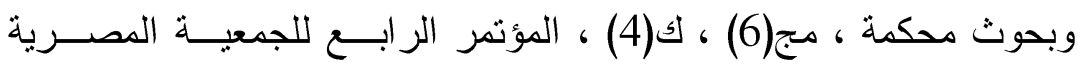

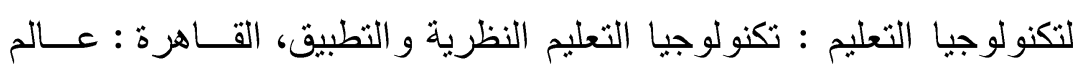

الكتب

16- غريغوري توماس ، وكيفية تصميم الشعار ات والرموز والأيقونات : وعـرض

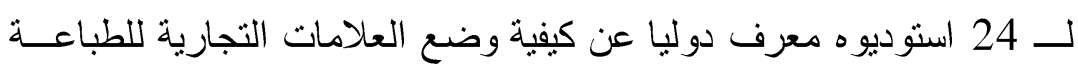

$$
\text { و الإعلام الجديد ، نيسان / ابريل } 2003 \text { ، ص ص } 48
$$

17 - كر اوثش، كريستوفر (2000 ) : العداثة في فن التصميم والعمـــارة، نيويــورك

$$
\text { : مانت مارثتز برس }
$$

18- مريام وبستر (1993) : قاموس وبستر. مكتبة لبنان: بيروت.

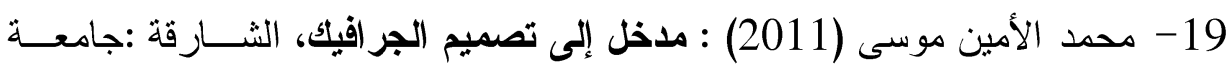
الشار قة .

\section{ثانياً: : المر لحع الاحنيسة}

20-Read Bain.(1973) : "Technology and State Government" American Sociological Review

21-R. Kelly Rainer, Efraim Turban.(2008) : Introduction to Information Systems: Supporting and Transforming Business. The United States of America: John Wiley \& Sons. 


\section{توظيف الإدراك البصري و التقتيات الجرافيكية في تصميم الصورة التطيمية}

\section{ملخص:}

يتسم عصرنا الحالي بالثقام العلمي و التقني الهائل و الذي ساهم في إحـــداث

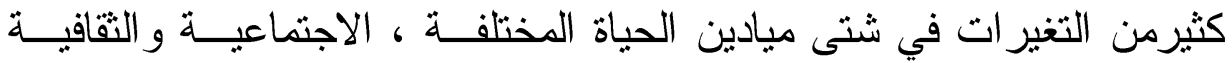

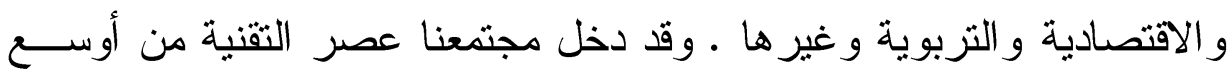

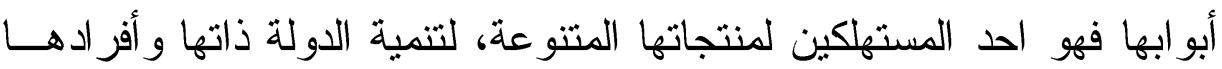
عليها مو اكبة غير ها من الدول المتقدمة و المتحضرة . تصميم الجر افيك أو التصميم الغرافيكي (فن الاتصالات البصرية) هو نهــــه إبداعي يقوم به مصمم أو مجموعة من المصممين ويتعاون على تتفيذ معطياته

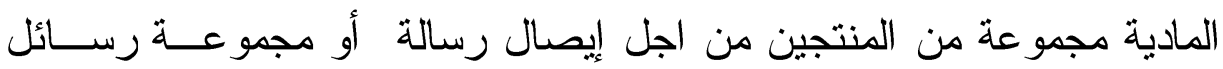
للمتعلم المستهدف يشير تصميم الجر افيك إلى كل من العملية (التصميم) التـي هني

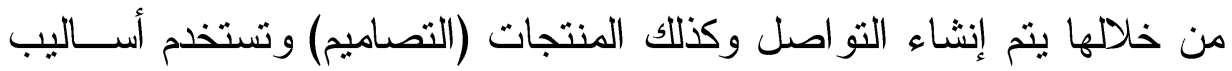

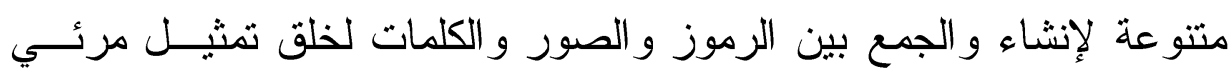
للأفكار و الرسائل.

وقد يستخدم مصمم الجر افيك تقنيات مثل فن الخط و الفنون البصرية، تتسيق

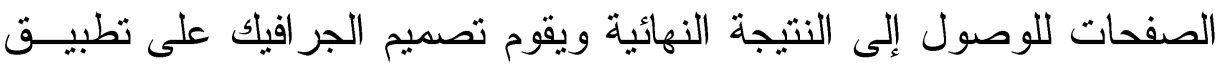

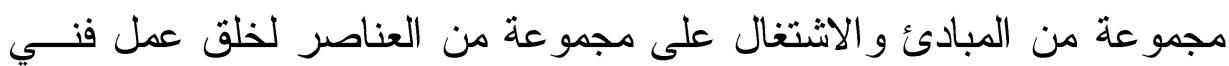

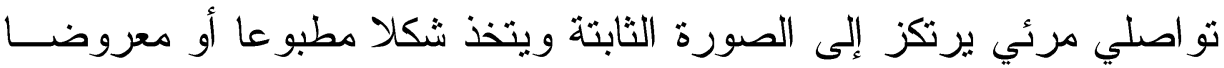

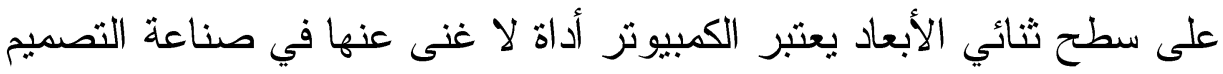
الجر افيكي.وبالنسبة إلى المحترفين من مصممي الجر افيك فان أجهزة الكمبيوتر وما لها من تطبيقات البرمجيات تعتبر بصورة عامة من الأدو ات الأكثر فعالية في مجال الإبداع الفني من الطرق التقليدية، و يمكن توظيف عناصر التصميم في إعداد الرسوم التعليمية وذلك للعمل علي انجاحها. 
Employment of visual perception and graphic techniques in the design of educational

\section{Abstract :}

Characterized our present scientific and technical progress and massive, who helped bring about many changes in the various fields of life, social, cultural, economic, educational, and others. Our society has entered the era of technology wider doors is one of the diverse consumers of their products, to develop the state itself and its members keep pace with other developed countries and civilized.

Graphic Design or Graphic Design (the art of visual communication) approach is creative play designer or group of designers and collaborate on the implementation of the givens physical group of producers in order to deliver a specific message (or group of letters) to the learner target refers graphic design to both the process (design)through which the communication is created as well as products.

And a variety of methods are used to create and combine symbols, images and words to create a visual representation of ideas and messages. It may be used graphic designer techniques such as line art, visual arts, coordinating thread to get to the final result and the graphic design on the application of a set of principles and engage in a range of elements to create a work of art communicative visual based to a still image and a form printed or displayed on a two-dimensional surface the computer is an indispensable tool in the graphic design industry .

For professional graphic designers, the computers and their software applications in general is one of the most effective tools in the field of artistic creativity than traditional methods, and design elements can be employed in the preparation of educational fees and to work to make it successful. 